\title{
Bid Promotes K63-Linked Polyubiquitination of Tumor Necrosis Factor Receptor Associated Factor 6 (TRAF6) and Sensitizes to Mutant SOD1- Induced Proinflammatory Signaling in Microglia ${ }^{1,2,3}$
}

\author{
Sinéad Kinsella, Hans-Georg König, and Jochen H.M. Prehn
}

DOI:http://dx.doi.org/10.1523/ENEURO.0099-15.2016

Department of Physiology and Medical Physics, Centre for the Study of Neurological Disorders, Royal College of Surgeons in Ireland, 123 St. Stephen's Green, Dublin 2, Ireland

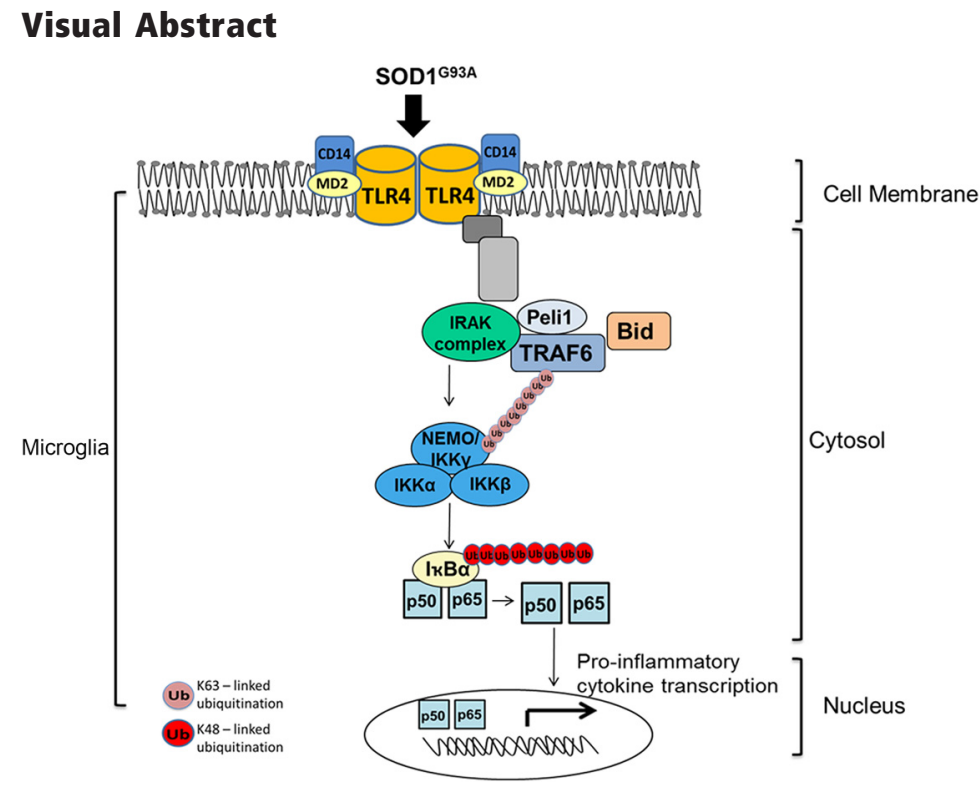

Mutations in the superoxide dismutase 1 (SOD1) gene contribute to motoneuron degeneration and are evident in $20 \%$ of familial amyotrophic lateral sclerosis cases. Mutant SOD1 induces microglial activation through a stimulation of Tolllike receptors 2 and 4 (TLR2 and TLR4). In the present study, we identified the proapoptotic $\mathrm{Bcl}-2$ family protein Bid as a positive regulator of mutant SOD1-induced TLR-nuclear factor- $\kappa \mathrm{B}$ $(\mathrm{NF}-\kappa \mathrm{B})$ signaling in microglia. bid-deficient primary mouse microglia showed reduced NF- $\kappa \mathrm{B}$ signaling in response to TLR4 activation or exposure to conditioned medium derived from $S O D 1^{\text {G93A }}$ expressing NSC-34 cells. Attenuation of NF- $\kappa \mathrm{B}$ signaling in bid-deficient microglia was associated with lower levels of phosphorylated $\mathrm{IKK} \alpha / \beta$ and $\mathrm{p} 65$, with a delayed degradation of $I_{\kappa} \mathrm{B} \alpha$ and enhanced degradation of Peli1. Up-

\section{Significance Statement}

Recent work suggests that many proapoptotic proteins also function in other cell-signaling pathways and may affect inflammatory responses. Inflammation is a hallmark of Amyotrophic Lateral Sclerosis (ALS) disease models, and inflammation-associated markers in ALS patients are associated with more severe disease progression. Here we demonstrate that the proapoptotic $\mathrm{Bcl}-2$ family protein Bid plays a crucial role in mutant SOD1-induced microglial activation, and delineate a novel signal transduction pathway activated by Bid involving K63-linked polyubiquitination of the E3 ubiquitin ligase tumor necrosis factor receptor associated factor 6 (TRAF6) and subsequent NF- $\kappa$ B activation. 
stream of IKK, we found that Bid interacted with, and promoted, the K63-linked polyubiquitination of the E3 ubiquitin ligase tumor necrosis factor receptor associated factor 6 (TRAF6) in microglia. Our study suggests a key role for Bid in the regulation of TLR4-NF- $\kappa \mathrm{B}$ proinflammatory signaling during mutant SOD1-induced disease pathology.

Bid promotes TLR4-NF- $\kappa$ B signaling by interacting with TRAF6 and promoting TRAF6 K63-linked polyubiquitination in microglia.

Key words: microglia; NF- $\kappa$ B; SOD1G93A protein; TLR; Toll-like receptor 4

\section{Introduction}

Amyotrophic lateral sclerosis (ALS) is a fatal, progressive neurodegenerative disease, characterized by the selective death of upper motoneurons in the cerebral cortex and lower motoneurons in the brainstem and anterior horn of the spinal cord (Ferraiuolo et al., 2011). Mutations in the superoxide dismutase 1 (SOD1) gene, linked to chromosome $21 \mathrm{q} 22.1$, account for $\sim 12-20 \%$ of the familial cases of ALS (Rosen et al., 1993; Renton et al., 2014). The cytotoxicity of mutant SOD1, a 153 aa cytosolic protein, is mainly described as a toxic gainof-function mechanism (Tu et al., 1996). Mutations in SOD1 lead to protein misfolding and aggregate formation (Rotunno and Bosco, 2013) and have been shown to induce endoplasmic reticulum (ER) stress and proteasomal dysfunction, which trigger several stressactivated disease processes in ALS (Kikuchi et al., 2006; Kieran et al., 2007). In addition, mutant SOD1 ${ }^{\text {G93A }}$ has been shown to have marked misfolding effects on wild-type SOD1 (Grad et al., 2011). Of note, it has become increasingly evident that non-cell autonomous toxicity mechanisms contribute to mutant SOD1induced motoneuron degeneration (Liu et al., 2009; Grad et al., 2011). Activation of both astrocytes and microglia are implicated in ALS pathogenesis with glial cell crosstalk contributing to the burden of inflammation (Hensley et al., 2006; Evans et al., 2013; Brites and Vaz, 2014). Studies have identified microglia to be phe-

Received August 28, 2015; accepted April 11, 2016; First published May 02, 2016.

${ }^{1}$ The authors declare no conflict of interest.

${ }^{2}$ Author contributions: S.K., H.-G.K., and J.H.M.P. designed research; S.K. performed research; S.K. and H.-G.K. analyzed data; S.K., H.-G.K., and J.H.M.P. wrote the paper.

${ }^{3}$ This work was supported by the BioAnalysis and Therapeutics PhD scholars program under the Programme for Research in Third Level Institutions (PRTLI) Cycle 5 and funding from the Science Foundation Ireland (08/INV.1/ B1949). The PRTLI is co-funded through the European Regional Development Fund, part of the European Union Structural Funds Programme 2007-2013. We thank Mathew King for the generation of the plasmids encoding the SOD1G93A-CFP fusion protein, Ina Woods and Shona Pfeiffer for proficient technical assistance in animal breeding, Caroline Jefferies for some valuable advice and for donating the Ubiquitin encoding plasmid, and Manuela Salvucci for assistance with statistical analyses.

Correspondence should be addressed to Jochen H. M. Prehn, Department of Physiology and Medical Physics, Royal College of Surgeons in Ireland, 123 St. Stephen's Green, Dublin 2, Ireland. E-mail: prehn@rcsi.ie.

DOI:http://dx.doi.org/10.1523/ENEURO.0099-15.2016

Copyright (C) 2016 Kinsella et al.

This is an open-access article distributed under the terms of the Creative Commons Attribution 4.0 International, which permits unrestricted use, distribution and reproduction in any medium provided that the original work is properly attributed. notypically neuroprotective at disease onset, however a proinflammatory activation state is soon acquired upon disease progression resulting in a chronic inflammatory pathology (Liao et al., 2012). Microglia expressing mutant SOD1 display elevated responses to inflammatory stimuli (Xiao et al., 2007; Sargsyan et al., 2009), and mutant SOD $1^{\text {G93A }}$ secreted from motoneurons activates microglia and induces neurotoxicity (Zhao et al., 2010).

Accumulating evidence demonstrates that mutant SOD1 induces increased Toll-like receptor (TLR) expression in ALS (Liu et al., 2009; Casula et al., 2011). TLRs are the master regulators of the cellular innate immune response (Scheffel et al., 2012), and are key mediators of the initiation and propagation of the inflammatory cascade in response to bacterial, viral or microbial nucleic acids, known as pathogenassociated-molecular-patterns (Kielian, 2006). TLR activation initiates several cascades of intracellular pathways, one of which leads to NF- $\kappa \mathrm{B}$ activation. $\mathrm{NF}-\kappa \mathrm{B}$ is a transcription factor and the major cytoplasmic facilitator of inflammatory stimuli. Recent evidence suggests that SOD1 ${ }^{\mathrm{G} 93 \mathrm{~A}}$ activates the transmembrane receptors TLR2 and TLR4 in a CD14-dependent manner (Zhao et al, 2010).

Previous studies observed increased levels of the $\mathrm{Bcl}-2$ family member Bid (BH3-interacting domain death agonist) in the spinal cords of SOD $1^{\text {G93A }}$ transgenic mice (Guégan et al., 2002; König et al., 2014). Bid is involved in the permeabilization of the mitochondrial outer membrane during death receptor activation, which leads to apoptosis (Wang et al., 1996). Recent research has suggested an immunoregulatory role of Bid (Mayo et al., 2011, Yeretssian et al., 2011; König et al., 2014). An interaction between Bid and the innate immune receptor nucleotide-binding and oligomerization domain was suggested, however this study did not demonstrate attenuated LPS-induced inflammation in the absence of Bid (Yeretssian et al., 2011). Reduced phagocytic functioning was revealed in bid-deficient microglia (Mayo et al., 2011), and Bid was shown to associate with the IKK complex upstream of NF- $\kappa \mathrm{B}$, specifically NEMO in intestinal epithelial cells (Yeretssian et al., 2011) and astrocytes (König et al., 2014). $\mathrm{NEMO} / \mathrm{IKK} \gamma$ is the regulatory subunit of the IKK complex $[\mathrm{IKK} \alpha$, IKK $\beta$, and IKK $\gamma / \mathrm{NEMO}(\mathrm{NF}-\kappa \mathrm{B}$ essential modulator)], activation of which is central to NF- $\kappa \mathrm{B}$ activation. We therefore set out to investigate the role of Bid as a positive regulator of mutant SOD1-induced TLR signaling in microglia, with a focus on Bid promotion of TLR4-NF- $\kappa$ B pathway activation. 


\section{Materials and Methods}

\section{Chemicals and antibodies}

Common chemicals were obtained from Sigma-Aldrich unless otherwise stated. Antibodies used for Western blotting and immunohistochemistry include rabbit anti-TLR2 (Abcam, ab108998; 1:500), rabbit anti-TLR4 (Santa Cruz Biotechnology, sc-10741; 1:100), anti-CD11b (Abcam, ab8878; 1:400), anti-plKK $\alpha / \beta$ (Cell Signaling Technology, 92465; 1:500), anti-IL-1 $\beta$ (Abcam, ab9722; 1:2000), antiTNF $\alpha$ (Abcam, ab9635; 1:500), anti-Bid (Enzo Laboratories, AR-52; 1:1000), anti-Peli1 (Abcam, ab13812; 1:1000), antipp65 (Cell Signaling Technology, 30315; 1:500), anti-I $\mathrm{B}^{\mathrm{B} \alpha}$ (Cell Signaling Technology, 9242; 1:500), anti-COX-II (BD Biosciences, 610203; 1:200), anti-TRAF6 (Santa Cruz Biotechnology, sc8409; 1:200), anti- $\alpha$-tubulin (Sigma-Aldrich, T6199, 1:5000), anti- $\beta$-actin (Sigma-Aldrich, A3853; 1:5000), anti-GAPDH (Abcam, ab8245-100;1:5000).

\section{Cell culture}

BV-2 cells, a murine cell line alternative to primary microglia commonly used to model the neuroinflammatory role of microglia (Henn et al., 2009), were cultured in RPMI containing $1 \%$ penicillin-streptomycin, $2 \mathrm{~mm}$ L-glutamine, and $10 \%$ fetal bovine serum. NSC-34 cells were kindly donated from the Shaw laboratory at the University of Sheffield, UK (originally generated by Cashman et al., 1992), and were cultured in DMEM with $4.5 \mathrm{~g} / \mathrm{L}$ glucose, $1 \%$ penicillin-streptomycin, $2 \mathrm{~mm}$ L-glutamine, and $10 \%$ fetal bovine serum. HEK293 deficient in TLR4 expression and HEK293/hTLR4-MD2-CD14 cells (kindly donated by Andrew Bowie, Trinity College Dublin, Ireland) were cultured in RPMI containing $1 \%$ penicillin-streptomycin, $2 \mathrm{~mm}$ L-glutamine, and $10 \%$ fetal bovine serum. HEK293-TLR4 media was supplemented with Blasticidin (InvivoGen; $10 \mu \mathrm{g} / \mathrm{ml}$ ), Normocin (InvivoGen; $100 \mu \mathrm{g} / \mathrm{ml}$ ), and Hygromycin B Gold (InvivoGen; $50 \mu \mathrm{g} / \mathrm{ml}$ ).

\section{Mixed glial-cell culture and microglial isolation}

All procedures involving animals were conducted under a license from the Department of Health and Children, as well as the Health Products Regulatory authority in Ireland. Procedures were reviewed by the Ethics Committee of the Royal College of Surgeons in Ireland. Mixed glial cultures were prepared from the cortices of P0-P2 WT and $\mathrm{bid}^{-1-}$ mice of mixed sexes on a C57BL/6 background. bid $^{-1-}$ mice were generated in the laboratory of Dr Andreas Strasser, WEHI, Melbourne, Australia (Kaufmann et al., 2007). The cortices were dissected and the meninges were removed before incubation in TrypsinEDTA at $37^{\circ} \mathrm{C}$ for $10 \mathrm{~min}$. DMEM-F12/L-glutamine (Gibco, Life Technologies) containing penicillin-streptomycin (1\%; Sigma-Aldrich) and fetal bovine serum (10\%; SigmaAldrich) was added to the cortices before trituration and passage through a $40 \mu \mathrm{m}$ nylon cell strainer (BD Falcon). The cells were centrifuged at $300 \times g$ for 6 min and the pellet was resuspended in DMEM-F12 containing Pen/ Strep and FBS. The cells were plated at a density of $\sim 4$ cortices $/ \mathrm{T} 75$ flask, and treated with M-CSF $(10 \mathrm{ng} / \mathrm{ml}$; R\&D Systems), and GM-CSF (20 ng/ml; R\&D Systems) from 1 day post-dissection to promote microglial prolifer- ation (Suzumura et al., 1990). Microglia were isolated using the shaking method. The media containing the detached and floating microglia was collected and centrifuged at $800 \times g$ for $6 \mathrm{~min}$. The pelleted isolated microglia were resuspended in DMEM-F12 (containing FBS and Pen/Strep) and plated at a density of $3.5 \times 10^{5}$ cells/well in a 6-well plate. The remaining cells were passaged and cultured in the absence of M-CSF and GM-CSF to obtain astrocyte cultures.

\section{Mixed primary motoneuron preparation}

Mixed primary cultures enriched for motoneurons were prepared from C57BL/6 murine WT E12 embryos by the dissection of the ventral horn of the spinal cord and subsequent purification, as previously described (Sebastià et al., 2009). In brief, the ventral horns were incubated with $0.025 \%$ trypsin in Neurobasal media for 10 $\mathrm{min}$, followed by gentle dissociation in the presence of 0.1 $\mathrm{mg} / \mathrm{ml}$ DNase1. The dissociated motoneurons were centrifuged at $300 \times g$ for 3 min and resuspended in complete Neurobasal media supplemented with $2 \mathrm{~mm}$ GlutaMAX, 2\% horse serum, 2\% B27, GDNF (Promega, Catalog \#2781; $2 \mathrm{ng} / \mathrm{ml}$ ), CNTF (R\&D Systems, Catalog \#557-NT-10; $1 \mathrm{ng} / \mathrm{ml}), 100 \mathrm{U} / \mathrm{ml}$ penicillin and $100 \mu \mathrm{g} / \mathrm{ml}$ streptomycin. The cells were seeded at a density of 0.25 $\times 10^{6}$ cells/well in a 24 -well plate pre-coated with polyornithine and laminin and cultured at $37^{\circ} \mathrm{C}$ in $5 \% \mathrm{CO}_{2}$. Motoneurons were harvested for Western blotting at 7 DIV.

\section{Generation of SOD1 ${ }^{\mathrm{G} 93 \mathrm{~A}}$ conditioned media}

NSC-34 cells were reverse transfected with $5 \mu \mathrm{g} / \mathrm{well}$ CFP or SOD $1^{\text {G93A }}$-CFP plasmid using Lipofectamine 2000 (1:2, DNA-Lipofectamine; Invitrogen) in Opti-MEM (Invitrogen) at a density of $4 \times 10^{5}$ cells/well in a 6 -well plate. After $4 \mathrm{~h}$ of incubation with the transfection mix, the cells were washed once with serum containing DMEM and incubated overnight in fresh DMEM containing full serum. The cells were then washed with serum free DMEM and incubated in the latter for $3 \mathrm{~d}$ before conditioned media was collected and centrifuged at $800 \times g$ for $5 \mathrm{~min}$ to remove cellular debris. Conditioned media was stored at $-20^{\circ} \mathrm{C}$ or concentrated on $10 \mathrm{kDa}$ size exclusion columns (10K, Amicon Ultra, UFC501096, Millipore) centrifuged at $4^{\circ} \mathrm{C}$ at $14,000 \mathrm{rpm}$ for $45 \mathrm{~min}$, boiled in Laemmli buffer for $5 \mathrm{~min}$, and ran on an acrylamide gel for quantification of SOD1 content in the media.

\section{Overexpression of SOD1 ${ }^{\mathrm{G} 93 \mathrm{~A}}$ in microglia}

BV-2 cells were transfected using electroporation (Amaxa Nucleofector II, Lonza). Briefly, the cells were harvested and a density of $5 \times 10^{6} \mathrm{cells} / 5 \mu \mathrm{g}$ plasmid was used for each cuvette. The cells were washed with RPMI (centrifuged at $90 \times g$ for $10 \mathrm{~min}$ ) and the pellet was resuspended in $100 \mu \mathrm{l}$ RPMl including $5 \mu \mathrm{g}$ pcDNA3-CFP (13030; Addgene), pcDNA-SOD1wt-CFP, or pcDNASOD1 ${ }^{\mathrm{G} 93 \mathrm{~A}}$-CFP and transfected via electroporation (program "A-023"). The transfected cells were carefully triturated in $1 \mathrm{ml}$ of RPMI and placed in the incubator for $1 \mathrm{~min}$ before being plated on 6-well plates. Cells were incubated for $8 \mathrm{~h}$ and lysed using Buffer RLT (Qiagen RNA 
easy kit) for mRNA extraction, or at $24 \mathrm{~h}$ in RIPA buffer for protein analysis. Primary microglia were transfected with

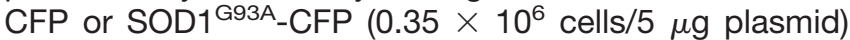
using Lipofectamine ( $2 \mu \mathrm{l} / \mu \mathrm{g}$ plasmid) and OptiMEM. The cells were incubated with the transfection mix for $2.5 \mathrm{~h}$ before being replaced with serum containing media. The cells were lysed in RLT buffer $24 \mathrm{~h}$ post-transfection for RNA extraction and qPCR analysis.

\section{qPCR analysis}

RNA was extracted using Qiagen RNAeasy kit and cDNA was synthesized using random primers and Superscript RTII (Invitrogen). qPCR analysis was carried out on a Roche Lightcycler 2.0 using SYBRgreen (Quantitect SYBRgreen kit, Qiagen). Two microliters of each cDNA sample and $18 \mu \mathrm{l}$ of the appropriate Mastermix [1 $\mu \mathrm{l} 10$ $\mu \mathrm{M}$ primer (forward and reverse), $10 \mu \mathrm{l}$ SYBRgreen PCR Mix, $7 \mu \mathrm{l}$ RNase-free $\mathrm{H}_{2} \mathrm{O}$ ] was added to give a total volume of $20 \mu \mathrm{l}$ per capillary tube. gapdh was used as an internal control for each sample analyzed. The cycle parameters were $95^{\circ} \mathrm{C}$ for $15 \mathrm{~min}, 94^{\circ} \mathrm{C}$ for $15 \mathrm{~s}, 57^{\circ} \mathrm{C}$ for 25 $\mathrm{s}, 72^{\circ} \mathrm{C}$ for $30 \mathrm{~s}$, and the annealing temperature for each primer was $57^{\circ} \mathrm{C}$. The primers used were as follows: gapdh (mouse) forward 5' AACTTTGGCATTGTGGAAGG $3^{\prime}$, reverse $5^{\prime}$ ACACATTGGGGGTAGGAACA $3^{\prime}$; t/r2 (mouse) forward 5' GCGGACTGTTTCCTTCTGAC 3', reverse 5' CCAAAGAGCTCGTAGCATCC 3'; tlr4 (mouse) forward 5' GCATGGCTTACACCACCTCT 3', reverse 5' GTCTCCACAGCCACCAGATT 3'. Primers were designed using Primer3 (http://biotools.umassmed.edu/bioapps/ primer3_www.cgi), and are between 150 and 250 base pairs, optimized for SYBR detection.

\section{Immunohistochemistry}

Primary microglia were fixed with $3 \%$ paraformaldehyde for $12 \mathrm{~min}$ at $37^{\circ} \mathrm{C}$, washed three times for $5 \mathrm{~min}$ in PBS, and blocked for $30 \mathrm{~min}$ at room temperature in blocking solution $[5 \%$ horse serum, $0.3 \%$ Triton X-100 (Sigma-Aldrich) in PBS]. After three washes with PBS the primary antibody [anti-CD11b (1:200) or anti-plKK $\alpha / \beta$ (1: $500)]$ was diluted in PBS $1 \%$ horse serum, $0.3 \%$ Triton $\mathrm{X}-100$ in PBS and added to the wells $(150 \mu \mathrm{l} / \mathrm{well}$ of 24-well plate), before incubation for $2 \mathrm{~h}$ at room temperature. The cells were washed three times with PBS and incubated in the dark with an AlexaFluor secondary antibody solution for $1 \mathrm{~h}$ at room temperature (1:500) in $1 \%$ horse serum, $0.3 \%$ Triton X-100 in PBS (anti-mouse AlexaFluor 488, Invitrogen A10037), anti-rabbit AlexaFluor 488 (Invitrogen, A21441), anti-rat AlexaFluor488 (Invitrogen, A11006), anti-mouse AlexaFluor 568 (Invitrogen, A10037), anti-rabbit AlexaFluor 568 (Invitrogen). Hoechst was used as a nuclear stain (Hoechst 33342, Invitrogen). Mean fluorescence was analyzed using Image $(\mathrm{NIH}$; imagej.nih.gov/ij).

\section{Co-immunoprecipitation and pull-down experiments}

Overexpression of tumor necrosis factor receptor associated factor 6 (TRAF6) was performed by transfection of the pCMV5-FLAG-wt-TRAF6 vector in BV-2 cells. In short, BV-2 cells were transfected with FLAG-wt-TRAF6 (Addgene, 21624) or pCMV5-FLAG $\left(1.5 \mu \mathrm{g} / 3 \times 10^{5}\right.$ cells) using Lipofectamine. The cells were stimulated with LPS for 1 or $4 \mathrm{~h}(1 \mu \mathrm{g} / \mathrm{ml} \mathrm{BV}-2$, or $100 \mathrm{ng} / \mathrm{ml}$ primary glia and astrocytes). Cells were lysed in RIPA buffer (Tris $50 \mathrm{~mm}$, $\mathrm{NaCl} 150 \mathrm{~mm}$, SDS $0.1 \%$, sodium-deoxycholate $0.5 \%$, Triton X-100 or NP-40 1\%, plus 1:100 Protease Inhibitor, Sigma-Aldrich). Co-immunoprecipitation or pull down experiments were performed using DynaBeads Protein G [35 $\mu$ l of Dynabeads/sample (100-400 $\mu \mathrm{g}$ protein), Life Technologies, 10007D], and a magnetic rack (Life Technologies). The beads were washed in RIPA buffer and incubated with $5 \mu \mathrm{g}$ primary antibody (in $200 \mu \mathrm{l}$ PBS for $30 \mathrm{~min}$ at room temperature). The beads were washed three times for 5 min in RIPA buffer and equal amounts of protein $(100 \mu \mathrm{g})$ were incubated rotating for $2 \mathrm{~h}$ at room temperature (in a total volume of $750 \mu \mathrm{l}$ ). The protein was eluted from the beads and denatured in RIPA buffer plus $1 \times$ Laemmli buffer by incubating for $10 \mathrm{~min}$ at $70^{\circ} \mathrm{C}$. The tubes were placed on the magnetic rack and the denatured supernatant was collected for gel electrophoresis.

\section{siRNA transfection}

An siRNA targeting Bid, sequence ACACGACUGUCAACUUUAU, was designed using an algorithm optimized for siRNA selection (Reynolds et al., 2004), and obtained from Sigma-Aldrich. Briefly, BV-2 cells were transfected with $100 \mu \mathrm{M}$ siRNA $/ 3 \times 10^{5}$ cells using Lipofectamine. Optimal silencing of bid was determined by qPCR analysis to be $48 \mathrm{~h}$ post-transfection. An siRNA consisting of a scrambled nucleotide sequence was used as the control in siRNA experiments.

\section{Western blot}

Media was aspirated from the cells and the wells were washed gently with PBS and lysed with $80 \mu \mathrm{l} / \mathrm{well}$ of 6 -well plate RIPA buffer for Western blot analysis. The cell lysates were incubated on ice for $15 \mathrm{~min}$ and centrifuged at $4^{\circ} \mathrm{C}$ at $13,000 \mathrm{rpm}$. The supernatants were used to determine the protein concentration by BCA assay (Micro BCA protein determination kit, Thermo Scientific). Laemmli buffer was added to each sample and the samples were boiled for $5 \mathrm{~min}$ and loaded onto $10 \%, 12 \%$, or $15 \%$ polyacrylamide gels as appropriate. Semi-dry transfer was performed on to PVDF membrane for $1.5 \mathrm{~h}$ at $18 \mathrm{~V}$. Membranes were exposed to Ponceau $S$ and blocked in $3 \%$ milk for $1 \mathrm{~h}$. Primary antibodies in $3 \%$ milk were incubated either overnight at $4^{\circ} \mathrm{C}$ or $2 \mathrm{~h}$ at room temperature. The membranes were washed in TBS-Tween 20 $(0.1 \%)$, and placed in $3 \%$ blocking solution containing the appropriate secondary antibody (peroxidase-conjugated anti-mouse IgG, anti-rabbit IgG, or anti-goat IgG, SigmaAldrich; 1:5000, as appropriate) for $2 \mathrm{~h}$ at room temperature. The membrane was washed three times for $5 \mathrm{~min}$ in TBS-Tween 20, exposed to ECL Chemiluminescent Reagent (Millipore) for $5 \mathrm{~min}$ and imaged on a LAS-3000 Imager (Fuji). Quantification of protein levels were calculated from optical density measurements from Western blot experiments and normalized to respective loading control ( $\alpha$-Tubulin, $\beta$-actin, or GAPDH). 


\section{Dual-luciferase assay}

BV-2 cells were cotransfected by reverse transfection with renilla and firefly luciferase reporter gene vectors (renilla luciferase plasmid: firefly luciferase plasmid, 1:12) in Opti-MEM (Sigma-Aldrich; $1 \mu \mathrm{g}$ plasmid per well/100 $\mu$ l) using X-tremeGENE HP Reagent (Roche; $2 \mu \mathrm{l} / \mu \mathrm{g}$ plasmid). Following $5 \mathrm{~h}$ incubation with transfection mix the cells were washed and incubated with BV-2 growth media (RPMI $+10 \%$ FBS, 1\% L-glutamine and 1\% Pen/Strep) overnight. BV-2 cells were treated with $100 \mu \mathrm{M}$ Bid Inhibitor (BI-6C9, Sigma-Aldrich), resuspended in DMSO, at a concentration $100 \mu \mathrm{M} 30 \mathrm{~min}$ prior to treatment with LPS (1 $\mu \mathrm{g} / \mathrm{ml}$; Sigma-Aldrich, Catalog \#L4391). BV-2 cells were lysed in $1 \times$ Passive Lysis Buffer (Promega) and luminescence was measured using Dual-Luciferase Assay Kit (Promega). HEK293 and HEK294-TLR4 cells were similarly cotransfected with constitutive renilla (phRL-TK) and firefly $\kappa \mathrm{B}$-luciferase reporter gene vectors [1:12 in OptiMEM using Lipofectamine $(2 \mu \mathrm{l} / 1 \mu \mathrm{g}$ plasmid)] by reverse transfection for $3 \mathrm{~h}$ before the cells were allowed to recover overnight in full serum media. After being washed gently with serum-free media both HEK293 and HEK293-TLR4 cells were stimulated with CFP or SOD1 ${ }^{\text {G93A-CFP }}$ conditioned media for 8 or $24 \mathrm{~h}$ before being lysed in passive lysis buffer, with luminescence measured using the method as above.

\section{Proximity ligation assay}

The in situ proximity ligation assay (PLA) was carried out using the Duolink system (DUO92101-1KT, SigmaAldrich). This technique allows the identification of proximity between epitopes of proteins in a complex in vitro by using hybridization between oligonucleotides linked to secondary antibodies when bound to primary antibodies against two specific proteins in close proximity $\leq 40 \mathrm{~nm}$ in situ (Soderberg et al., 2006). Here we used mouse antiTRAF6 (1:100) and rabbit anti-Bid (1:500; Abcam, ab62469) as primary antibodies to determine close proximity. BV-2 cells were plated in a 96-well plate and transfected with either pCMV-Myc-FLAG or pCMV-FLAGTRAF6wt (Plasmid 21624, Addgene) at a concentration of $0.075 \mu \mathrm{g} / 2 \times 10^{4}$ cells. Twenty-four hours posttransfection the cells were exposed to serum free media 2 $\mathrm{h}$ prior to treatment with either vehicle $(1 \times \mathrm{PBS})$ or LPS $(1$ $\mu \mathrm{g} / \mathrm{ml})$. The cells were immunostained as described above. Controls included combinations of mouse antiTRAF6 (1:100) plus rabbit anti-HA-tag (1:500; Santa Cruz Biotechnology, sc805), and rabbit anti-Bid plus mouse anti-IRF2 (1:500; Santa CruzBiotechnology, sc101069). PLA probes were diluted in primary antibody diluent $(1 \%$ horse serum and $0.3 \%$ Triton $\mathrm{x}-100$ in PBS) at a ratio of $1: 10$ and incubated for $1 \mathrm{~h}$ at $37^{\circ} \mathrm{C}$. The ligation stock was diluted (1:5) with high-purity $\mathrm{H}_{2} \mathrm{O}$ and ligase 1:40. Twenty microliters per well of ligation-ligase solution was incubated with the cells at $37^{\circ} \mathrm{C}$ for $30 \mathrm{~min}$. The cells were incubated with the amplification solution (1:5 with highpurity $\mathrm{H}_{2} \mathrm{O}$ and $1: 40$ polymerase) for $100 \mathrm{~min}$ at $37^{\circ} \mathrm{C}$. The cells were washed three times with PBS and Hoechst was used as a nuclear stain (1:1000 in PBS, Hoechst 33342). The wells were imaged in order to detect amplification dots representing TRAF6-Bid close-proximities and analysis was performed using ImageJ software.

\section{Statistical analysis}

Statistical analysis was performed using GraphPad Prism software or MATLAB software (v2014b, MathWorks) as applicable. Results are represented as mean \pm SEM. Statistical significance was determined using the tests as detailed in the respective figure legends and Table $1(* p \leq 0.05)$.

\section{Results}

\section{SOD1 ${ }^{\text {G93A }}$ overexpression increases TLR2 and TLR4 levels and COX-2 activation in microglia}

To explore the role of TLRs in SOD1 disease pathology, we analyzed t/r2 and t/r4 expression in response to overexpressed SOD1 ${ }^{\mathrm{G} 93 \mathrm{~A}}$ in microglia. BV-2 cells transiently transfected with mutant SOD $1^{\mathrm{G} 93 \mathrm{~A}}$ exhibited a significant increase in t/r2 (Fig. 1A; 2.17-fold \pm 0.84) and t/r4 (Fig.1B; 1.55 -fold \pm 0.37 ) mRNA levels. We also observed increased TLR2 (Fig. 1C,E; 1.6-fold \pm 0.51) and TLR4 (Fig. $1 D, F ; 1.72$-fold \pm 0.37 ) protein levels in SOD1G93A. transfected BV-2 cells compared with CFP-control transfected cells, analyzed by Western blotting. These results suggested that the presence of SOD1 ${ }^{\mathrm{G} 93 \mathrm{~A}}$ primed microglia for increased TLR2 and 4 signaling.

Cyclooxygenase-II (COX-II), an enzyme that is induced in response to proinflammatory stimuli (Nadjar et al., 2005; Laflamme et al., 1999), is recognised as a target gene of NF- $\kappa$ B activation (Nakao et al., 2000; Nadjar et al., 2005). We found significantly increased COX-II levels in response to transient transfection of BV-2 cells with SOD1 ${ }^{\text {G93A }}$ (Fig. 1G,H; 2.07-fold \pm 1.11 increase), and following paracrine stimulation with $\mathrm{SOD} 1^{\mathrm{G} 93 \mathrm{~A}}$ conditioned media (Fig. 1l,J; 2.1 -fold \pm 0.33 increase). COX-II levels were not significantly induced in TLR2 and TLR4inhibited BV-2 cells, using the small molecule inhibitor OxPAPC, which were stimulated with NSC-34-derived SOD1 ${ }^{\mathrm{G} 93 \mathrm{~A}}$-conditioned media (Fig. 1/,J). OxPAPC (1palmitoyl-2-arachidonyl-sn-glycero-3-

phosphorylcholine), an oxidized phospholipid, was used here to selectively inhibit TLR2 and TLR4 dimerization by interacting with MD2, LPS-binding protein, and CD14, an extracellular receptor which is indispensable for both TLR2 and TLR4 dimerization (Fitzgerald et al., 2004; Erridge et al., 2008), thus blocking TLR2- and TLR4-induced activation. Additionally, COX-II levels were significantly lower in OxPAPC treated cells stimulated with SOD1 G93A_ conditioned media compared with control cells exposed to the same stimulus (Fig. 1l,J; 2.2-fold \pm 0.407 decrease), suggesting that SOD1 ${ }^{\mathrm{G} 93 \mathrm{~A}}$ elicited its toxicity through TLR-NF- $\kappa$ B signaling. Next HEK293 cells that are deficient in TLR4 (Stack and Bowie, 2012) and HEK293 cells stably expressing TLR4 were exploited to demonstrate the requirement of TLR4 in SOD1 ${ }^{\mathrm{G} 93 \mathrm{~A}}$-mediated $\mathrm{NF}-\kappa \mathrm{B}$ activation. HEK293 cells stably expressing TLR4 showed increased NF- $\kappa \mathrm{B}$ activation, as measured by $\mathrm{NF}-\kappa \mathrm{B}$ reporter firefly luciferase readout in response to stimulation in paracrine with SOD1 ${ }^{\mathrm{G} 93 \mathrm{~A}}$ (Fig. $1 K$; 1.35 -fold \pm 0.31 increase), with no increased NF- $\kappa \mathrm{B}$ activation 
Table 1. Statistical table

\begin{tabular}{|c|c|c|c|}
\hline Label & Data structure & Type of test & Significance \\
\hline Fig. $1 \mathrm{~A}$ & Nonparametric & Paired two-tailed $t$ test & $\begin{array}{l}n=8-10 \text { cultures } \\
p=0.0156\end{array}$ \\
\hline Fig. 1B & Nonparametric & Paired two-tailed $t$ test & $\begin{array}{l}n=8-9 \text { cultures } \\
p=0.007\end{array}$ \\
\hline Fig. 1E & Nonparametric & Paired two-tailed $t$ test & $\begin{array}{l}n=6 \text { cultures } \\
p=0.031\end{array}$ \\
\hline Fig. 1F & Nonparametric & Paired two-tailed $t$ test & $\begin{array}{l}n=6 \text { cultures } \\
p=0.031\end{array}$ \\
\hline Fig. $1 \mathrm{H}$ & Nonparametric & Paired two-tailed $t$ test & $\begin{array}{l}n=3 \text { cultures } \\
p=0.0106\end{array}$ \\
\hline Fig. 1J & Parametric & One-way ANOVA, Tukey post-hoc test & $\begin{array}{l}n=3 \text { cultures } \\
\mathrm{p}=0.0021\end{array}$ \\
\hline Fig. $1 \mathrm{~K}$ & Parametric & Paired two-tailed $t$ test & $\begin{array}{l}n=11 \text { wells from } 2 \\
\text { separate experiments } \\
p=0.0216 \text { HEKTLR } 4 \\
\text { cells CFP vs SOD1G93A }\end{array}$ \\
\hline Fig. 2C & Parametric & $\begin{array}{l}\text { One-way ANOVA, Bonferroni's } \\
\text { multiple-comparison test }\end{array}$ & $\begin{array}{l}n=4-6 \text { cultures } \\
p=0.027\end{array}$ \\
\hline Fig. 3C & Parametric & Three-way ANOVA, Tukey post hoc test & $\begin{array}{l}n=3 \text { cultures } \\
p=0.0147 \text { WT vs bid }\end{array}$ \\
\hline Fig. 3G & Parametric & $\begin{array}{l}\text { One-way ANOVA, Tukey's } \\
\text { multiple-comparison test }\end{array}$ & $\begin{array}{l}n=7 \text { cultures } \\
p=0.0162\end{array}$ \\
\hline Fig. $3 \mathrm{H}$ & $\begin{array}{l}\text { Nonparametric } \\
\text { Grubbs outlier removal }\end{array}$ & $\begin{array}{l}\text { Kruskal-Wallis test, Dunn's } \\
\text { multiple-comparison post hoc test }\end{array}$ & $\begin{array}{l}n=6-16 \text { cultures } \\
\text { DMSO LPS vs DMSO Veh } \\
p<0.0001 \\
\text { BI Veh vs DMSO Veh } \\
p=0.6926 \\
\text { BI LPS vs DMSO Veh } \\
p=0.5933 \\
\text { BI Veh vs DMSO LPS } \\
p<0.0001 \\
\text { BI LPS vs DMSO LPS } \\
p=0.0162 \\
\text { BI LPS vs BI Veh } \\
p=0.0162\end{array}$ \\
\hline Fig. $4 B$ & Parametric & Three-way ANOVA, Tukey post hoc test & $\begin{array}{l}n=3 \text { cultures } \\
p=0.000823 \\
\text { WT vs } \text { bid }\end{array}$ \\
\hline Fig. $5 F$ & Nonparametric & $\begin{array}{l}\text { Kruskal-Wallis, Dunn's } \\
\text { multiple-comparison post hoc test }\end{array}$ & $\begin{array}{l}p=0.0378 \\
\text { minus LPS vs plus LPS }\end{array}$ \\
\hline Fig. $6 F$ & Nonparametric & $\begin{array}{l}\text { Kruskal-Wallis, Dunn's } \\
\text { multiple-comparison post hoc test }\end{array}$ & $\begin{array}{l}n=3 \text { cultures } \\
p=0.0509\end{array}$ \\
\hline
\end{tabular}

observed in HEK293 cells devoid of TLR4. These data support the previous findings by Zhao et al. (2010) and points toward a TLR4-dependent mechanism of action of SOD1 ${ }^{\text {G93A. }}$

\section{bid $^{-1-}$ microglia show reduced NF- $\mathrm{B}$ activation upon TLR4 stimulation}

To investigate the involvement of Bid in microglial immune responses we examined Bid protein levels in resting WT mixed motoneurons, astrocytes, and microglia. We found higher levels of Bid protein in astrocytes and microglia (Fig. 2A,B; astrocytes 5.9-fold \pm 2.78 , microglia 6.2-fold \pm 2.08 ), verifying previous findings (König et al., 2014). To investigate the effects of Bid deficiency on SOD1 ${ }^{\text {G93A }}$ induced microglial t/r4 mRNA expression we generated WT and bid $^{-1-}$ primary microglia cultures and transiently transfected the microglia with CFP or SOD1 ${ }^{\text {G93A-CFP. } t / r 4}$ expression was higher in SOD1 ${ }^{\text {G93A }}$-overexpressing wildtype microglia compared with bid-deficient microglia (Fig.
$2 C$; 2.9 -fold \pm 1.2 increase vs 0.8 -fold \pm 0.9 decrease). t/r4 mRNA levels did not significantly increase in wild-type microglia overexpressing SOD1 ${ }^{\text {G93A }}$ compared with CFPtransfected microglia, but increased TLR4 protein levels were detected in SOD1 ${ }^{\mathrm{G} 93 \mathrm{~A}}$-overexpressing BV-2 cells (Fig. 1D,F).

To additionally investigate the effect of a lack of Bid on TLR4-induced proinflammatory signaling in microglia both WT and bid $^{-1-}$ microglia were stimulated with the well characterized TLR4 agonist LPS (Takeuchi et al., 1999). Of note, both TLR2 and TLR4 signal to NF- $\kappa$ B via the MyD88-dependent pathway (Akira and Hoshino, 2003). Wild-type and bid $^{-1-}$ microglia were stimulated with LPS for $4 \mathrm{~h}$ and lysed for Western blot analysis of the cytokine IL-1 $\beta$ and TNF $\alpha$ levels. IL-1 $\beta$ was used as a proinflammatory marker as IL-1 $\beta$ has been shown to be rapidly secreted in response to LPS (Dinarello, 1997) and to be critical in the NF- $\kappa \mathrm{B}$ induction of COX-II-derived prostaglandins in the CNS (Laflamme et al., 1999). TNF $\alpha$ 

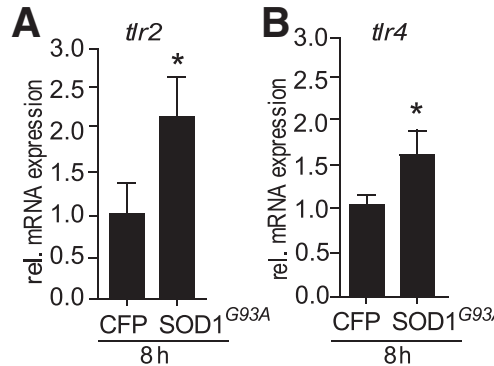

I

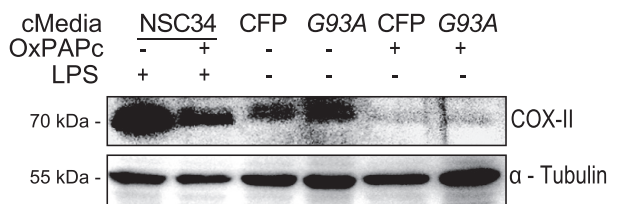

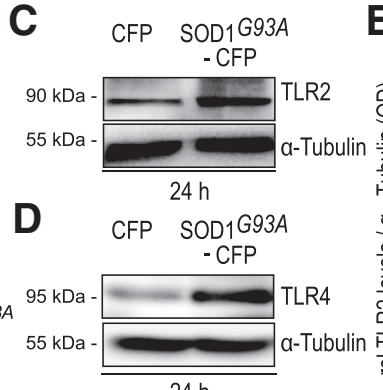

$24 \mathrm{~h}$
E

E
G

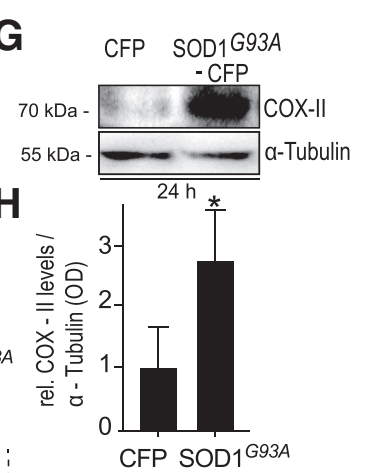

Figure 1. TLR2 and TLR4 expression is increased in response to SOD1 G93A overexpression. BV-2 cells were transiently transfected

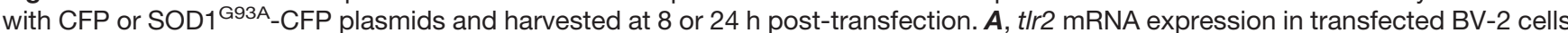
was measured at $8 \mathrm{~h}$ post-transfection by qPCR analysis, relative to control gene gapdh ( $n=8-10$ wells pooled from 3 separate experiments; Kruskal-Wallis, Dunn's multiple-comparison post hoc test). $\boldsymbol{B}$, tIr4 mRNA was analyzed by qPCR analysis of BV-2

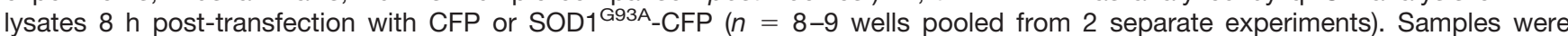
normalized to internal control gapdh. $\boldsymbol{C}, \boldsymbol{E}$, TLR2 protein levels in CFP or SOD1 G93A-CFP-transfected BV-2 cells analyzed by Western blot. BV-2 cells were lysed in RIPA buffer $24 \mathrm{~h}$ post-transfection via nucleofection (normalized to $\alpha$-Tubulin OD, $n=6$ wells pooled from 4 separate experiments; $p=0.031$, two-tailed paired $t$ test). $\boldsymbol{D}, \boldsymbol{F}$, TLR4 protein levels in CFP or SOD1 G93A-CFP-transfected BV-2 cells analyzed by Western blot. BV-2 cells were lysed in RIPA buffer 24 h post-transfection via nucleofection (normalized to $\alpha$-Tubulin OD $\mathrm{n}=6$ wells pooled from 4 separate experiments; $p=0.031$, two-tailed paired $t$ test). $\mathbf{G}, \boldsymbol{H}$, COX-II levels were assessed in SOD1 ${ }^{\text {G93A }}$ overexpressing BV-2 cells ( $n=3$ cultures from 2 separate platings; $p=0.016$, two-tailed paired $t$ test). BV-2 cells were

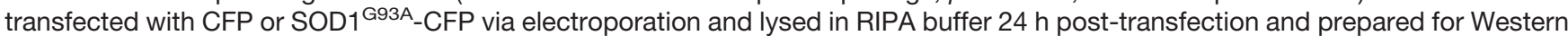
blot analysis. I, J, COX-II levels in TLR2- and TLR4 -inhibited BV-2 cells following stimulation with CFP or SOD1 G93A cMedia. BV-2 cells were treated with OxPAPC $(30 \mu \mathrm{g} / \mathrm{ml})$ simultaneous to cMedia treatment. Cells were lysed $24 \mathrm{~h}$ post-cMedia stimulation and prepared for Western blot analysis ( $n=3$ wells, $p=0.002$, one-way ANOVA, Tukey's multiple comparison post hoc test). $\boldsymbol{K}$, NF- $\boldsymbol{B}$ activity in TLR4-deficient HEK293 and HEK293-TLR4-stably expressing cells stimulated with SOD1G93A conditioned media. HEK293 and HEK293-TLR4 were cotransfected with $\kappa$ B-RE-luciferase and RLTK-Renilla-luciferase for normalization for 24 h and subsequently stimulated with CFP or SOD1 ${ }^{\text {G93A }}$ cMedia for 8 or $24 \mathrm{~h}$. The cells were lysed in passive lysis buffer and measured as $\kappa$ B-dependent firefly activity normalized to renilla luciferase activity per well $(n=11$ wells pooled from 2 separate experiments; $p=0.021$, two-tailed paired $t$ test between HEK-TLR4 treated cells). Conditioned media was generated by overexpression of CFP or SOD1G93A-CFP vectors in NSC-34 cells, with serum-free conditioned media collected $3 \mathrm{~d}$ post-transfection.

is a proinflammatory cytokine secreted in response to LPS (Sawada et al., 1989), and microglial secretion of TNF $\alpha$ is shown to induce motoneuron death in vitro (He et al., 2002). Analysis revealed substantially reduced proinflammatory cytokine IL-1 $\beta$ and TNF $\alpha$ production (Fig. $2 \mathrm{D}, \mathrm{E})$ in bid-deficient microglia compared with wild-type cells $4 \mathrm{~h}$ post stimulation with LPS.

Because microglia are the first line of immune response in CNS pathogenesis we investigated the effect of biddeficiency on microglial TLR4-NF- $\kappa$ B activation following acute LPS stimulation. LPS-induced activation of the IKK complex leads to $I_{\kappa} \mathrm{B} \alpha$ degradation, in a phosphorylationinduced and proteasome-dependent manner (Alkalay et al., 1995; Brown et al., 1995; Yang et al., 2003). Wildtype and $\mathrm{bid}^{-/-}$microglia were stimulated with LPS for 5 min, fixed in $3 \%$ formaldehyde and stained with antiCD11b and anti-plKK $\alpha / \beta$. CD11b is a cluster of differentiation molecule that is highly expressed in cells of the innate immune system, including macrophages and microglia, and is involved in mediating inflammation by regulating migration and adhesion properties. CD11b was used as a microglial marker and the fluorescence intensity of plKK $\alpha / \beta$ was measured on CD11b-expressing cells. Overall decreased immunofluorescence of phosphorylated IKK $\alpha / \beta$ was noted in LPS-stimulated Bid-deficient microglia compared to wild-type CD11b-positive cells (Fig. 3A). Western blot analysis of microglia stimulated acutely with LPS, for $5,15,30$, min or $1 \mathrm{~h}$, showed significantly less phosphorylation of $\mathrm{IKK} \alpha / \beta$ and less phosphorylated p65 in bid $^{-/-}$microglia compared with WT upon LPS stimulation from $5 \mathrm{~min}$ to $1 \mathrm{~h}$ (Fig. $3 B, C$ ). The degradation profile of the NF- $\kappa \mathrm{B}$ inhibitor $1 \kappa \mathrm{B} \alpha$ was measured as an indicator of TLR4-NF- $\kappa$ B activation (Fig. $3 D, E)$ and demonstrated that bid-deficiency delayed signal-induced degradation of $I_{\kappa} \mathrm{B} \alpha$ noted at $30 \mathrm{~min}$ and 1 $\mathrm{h}$ post LPS stimulation, confirming previous results (Mayo 
A
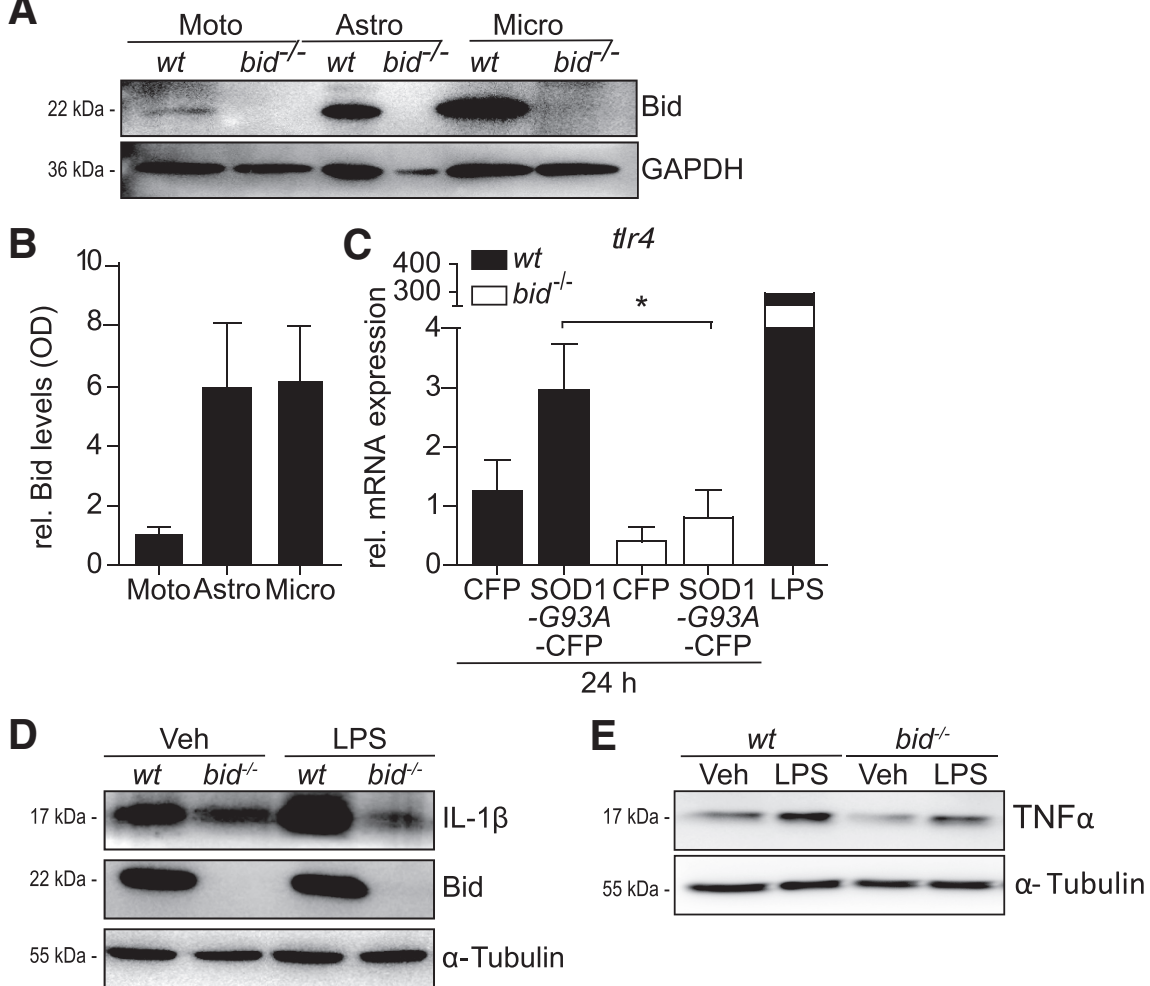

Figure 2. Bid is highly expressed in microglia, SOD1 ${ }^{\mathrm{G} 93 \mathrm{~A}}$-overexpressing bid-deficient microglia express reduced t/r4 mRNA levels

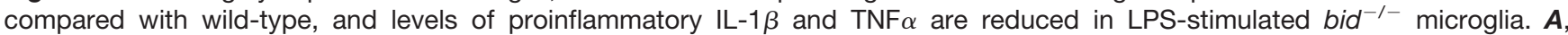
Representative Western blot showing Bid levels and $(\boldsymbol{B})$ quantification of optical density analysis of Bid levels in motoneurons, astrocytes and microglia. Primary mixed motoneurons were harvested at 7DIV, and purified astrocytes and isolated microglia were lysed $2 \mathrm{~d}$ post-plating to allow time for the cells to become quiescent. Bid protein levels were examined, by Western blot, in purified astrocytes and microglia at rest compared with motoneurons. Bid protein levels were assessed by measuring the optical densities of each sample relative to that of the respective loading control (B; GAPDH or $\beta$-actin, experiment was repeated 3 times with similar

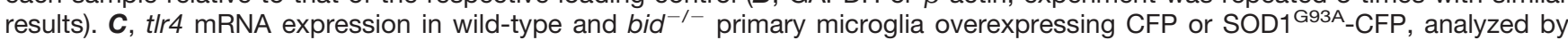
qPCR. Samples were normalized to internal control gapdh $(n=4-6$ wells pooled from 2 separate experiments; $p=0.027$, one-way ANOVA, Bonferroni's multiple-comparison post hoc test). $\boldsymbol{D}, \mathrm{IL}-1 \beta$ levels were analyzed by Western blot in wild-type and bid ${ }^{-1-}$ microglia $4 \mathrm{~h}$ post-LPS treatment. $\boldsymbol{E}$, TNF $\alpha$ levels were analyzed in wild-type and bid-deficient microglia $4 \mathrm{~h}$ post-LPS stimulation. Wild-type and $\mathrm{bid}^{-1-}$ microglia were stimulated with vehicle, LPS (100 ng/ml) for $4 \mathrm{~h}$ before being harvested with RIPA lysis buffer and used for Western blot analysis.

et al., 2011). Interestingly there was a delay in recovery of $I_{\kappa} \mathrm{B} \alpha$ levels at $2 \mathrm{~h}$ post LPS stimulation in the $\mathrm{bid}^{-1-}$ microglia compared with wild-type, suggesting a delay in the positive feedback response in the absence of bid. Additionally, the phosphorylation of $\mathrm{p} 65$ was significantly induced in wild-type microglia but not in bid-deficient microglia $1 \mathrm{~h}$ post LPS stimulation (Fig. 3F,G; 3.7-fold \pm 1.3 increase vs 2.7 -fold \pm 0.8 increase).

$\mathrm{NF}-\kappa \mathrm{B}$ transactivation potential, as measured by $\kappa \mathrm{B}-$ response element-dependent luciferase expression, was also significantly reduced when Bid was inhibited using $100 \mu \mathrm{M}$ of the small molecule Bid inhibitor (BI-6C9) prior to LPS stimulation (24 h) in BV-2 cells (Fig. $3 \mathrm{H}$; BI-6C9 + LPS decreased $3.00 \pm 1.858$-fold compared with DMSO + LPS). COX-II levels were assessed in Bid-depleted BV-2 cells following stimulation in paracrine with SOD1 ${ }^{\text {G93A }}$. BV-2 cells were transfected with siRNA targeting Bid followed by stimulation with SOD1 ${ }^{\text {G93A }}$ in cMedia. Western blot analysis determined reduced COX-II levels in

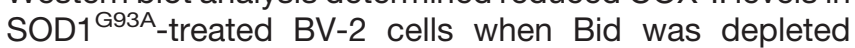

compared with control siRNA-transfected BV-2 cells exposed to the same SOD1 ${ }^{\text {G93A }}$ stimulus (Fig. 3l,J; 1.6-fold \pm 0.8 increase vs 0.8 -fold \pm 0.6 decrease) .

\section{Reduced levels of Peli1 in bid $^{-/-}$microglia upon TLR4 activation}

A number of E3 ubiquitin ligases regulate NF- $\kappa$ B signaling and activation. Peli1 is responsible for catalyzing the K63linked polyubiquitination of the Interleukin-1 receptorassociated kinase (IRAK) complex (Moynagh, 2009) and has been described as a key regulator of CNS inflammatory pathogenesis (Song and Qian, 2013). Wild-type and $\mathrm{bid}^{-1-}$ microglia were stimulated with LPS acutely as above, and lysed for Western blot analysis. Overall, Peli1 levels were significantly lower in bid-deficient microglia at early time-points post LPS stimulation (from $5 \mathrm{~min}$ to $1 \mathrm{~h}$ post-treatment) compared with wild-type microglia (Fig. $4 A, B$; WT microglia $1.49 \pm 0.57$-fold increased vs 0.59 \pm 0.46 -fold decreased in $\mathrm{bid}^{-1-}$ at $1 \mathrm{~h}$ LPS time point). 
A

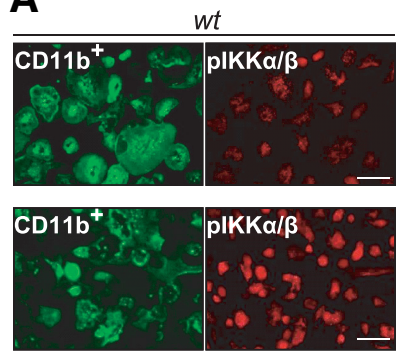

B

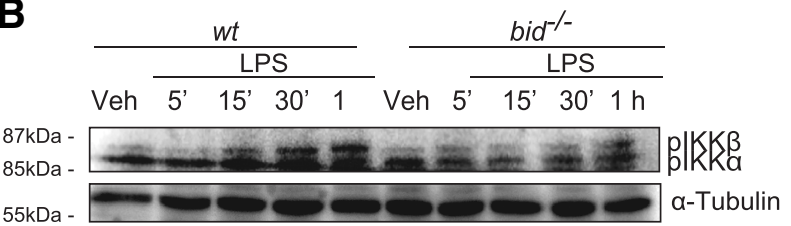

C

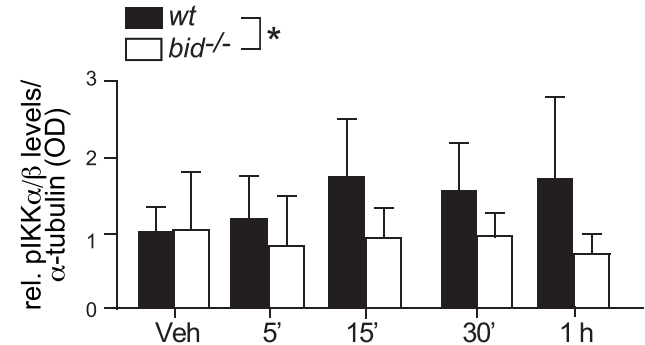

D

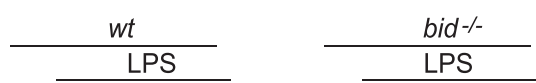

Veh $5^{\prime} \overline{15^{\prime} 30^{\prime} 1 \mathrm{~h} 2 \mathrm{~h}}$ Veh $5^{\prime} 15^{\prime} 30^{\prime} 1 \mathrm{~h} 2 \mathrm{~h}$

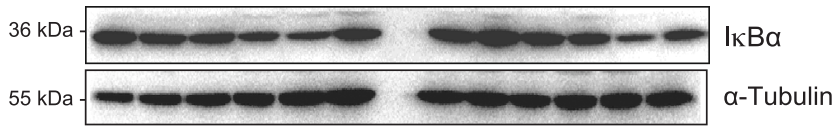

E

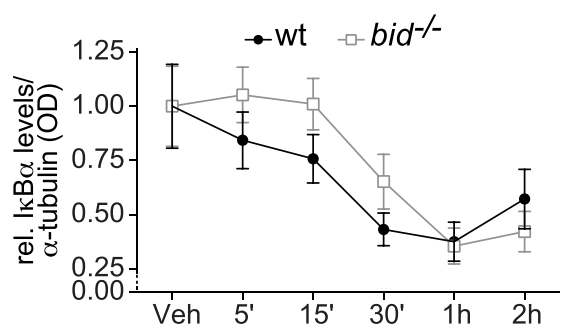

$\mathbf{F}$

Vehicle

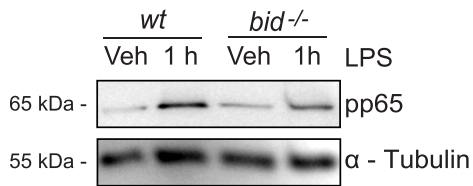

H

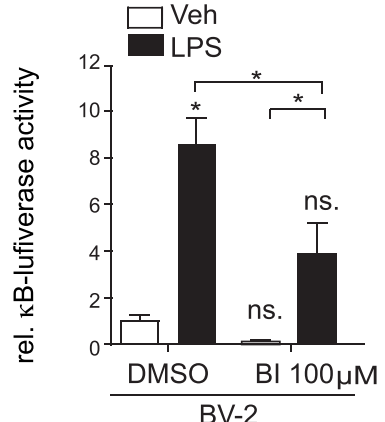

I

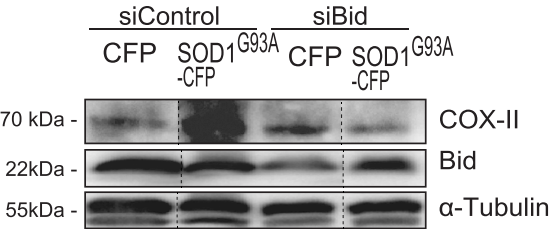

BV-2

J

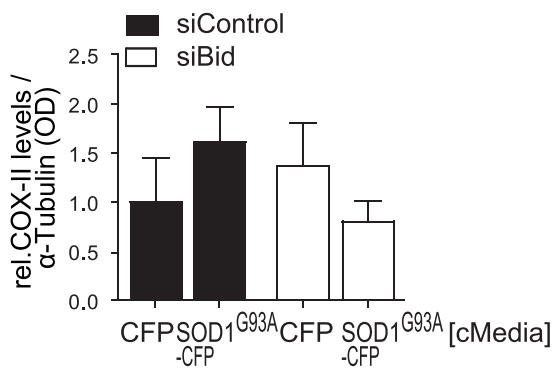

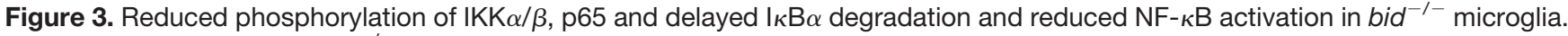
$\boldsymbol{A}$, Primary wild-type and $\mathrm{bid}^{-1-}$ microglia were stimulated with LPS for 5-30 min in serum-free media before being fixed in 3\% paraformaldehyde and stained with anti-phosphorylated $\mathrm{IKK} \alpha / \beta(\mathrm{plKK} \alpha / \beta)$ and anti-CD11b. Immunohistochemistry analysis of anti-plKK $\alpha / \beta$ mean fluorescence on CD11b-positive cells is depicted. Scale bar, $50 \mu \mathrm{M}$. $\boldsymbol{B}$, $\boldsymbol{C}$, Primary wild-type and bid ${ }^{-1-}$ microglia $^{-}$ were treated with LPS for $5,15,30 \mathrm{~min}$, or $1 \mathrm{~h}$ in serum-free media before being lysed for Western blot analysis of plKK $\alpha / \beta$ protein levels $\left(n=3\right.$ pooled from 3 separate experiments; $p=0.014$, 3-way ANOVA, Tukey post hoc test). $\boldsymbol{D}, \boldsymbol{E}$, Wild-type and bid $^{-1-}$ microglia were stimulated with LPS for $5 \mathrm{~min}$ to $2 \mathrm{~h}$ in serum-free media, lysed in RIPA buffer and $I_{\kappa} \mathrm{B} \alpha$ levels were analyzed by Western blot ( $n=3-4$ wells from 3-4 separate experiments). $\boldsymbol{F}, \mathbf{G}$, Wild-type and bid $^{-1-}$ microglia were stimulated with LPS for $1 \mathrm{~h}$ before being lysed in RIPA buffer. pp65 levels were assessed by Western blot $(n=7$ wells pooled from 6 separate experiments; $p$ $=0.0162$, one-way ANOVA, Tukey's post hoc test). $\boldsymbol{H}$, BV-2 cells were cotransfected with NF- $\kappa$ B-RE-luciferase and renilla-luciferase plasmids for $24 \mathrm{~h}$ and subsequently treated with LPS for $24 \mathrm{~h}$. The cells were lysed in passive lysis buffer and NF- $\kappa \mathrm{B}$ activation was quantified by dual luciferase assay (represented as relative $\kappa$ B-dependent firefly activity, $n=6-16$ wells pooled from 2 separate experiments, 2 outliers removed, Grubbs test followed by Kruskal-Wallis and Dunn's multiple-comparison post hoc test). $\boldsymbol{I}$, $\boldsymbol{J}$, COX-II levels in Bid-depleted BV-2 cells stimulated with CFP or SOD1 ${ }^{\mathrm{G} 93 \mathrm{~A}}$ cMedia. BV-2 cells were transfected with an siRNA targeting Bid ("siBid") or a scrambled control siRNA ("siControl"), and stimulated with cMedia $48 \mathrm{~h}$ post-siRNA transfection, when Bid levels were optimally reduced. Twenty-four hours post-cMedia treatment the cells were lysed in RIPA and COX-II levels were measured. Dashed line indicated irrelevant lanes spliced out. Quantification of optical density was normalized to anti- $\alpha$-tubulin for each Western blot ( $n=3$, from 3 separate experiments). 
A

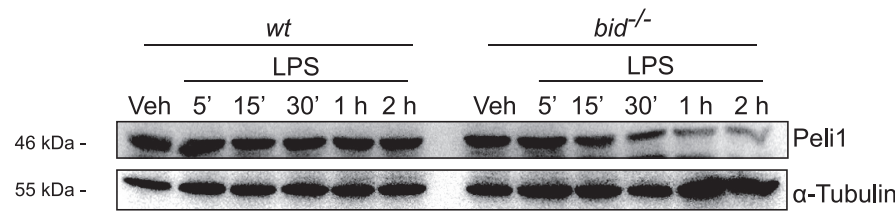

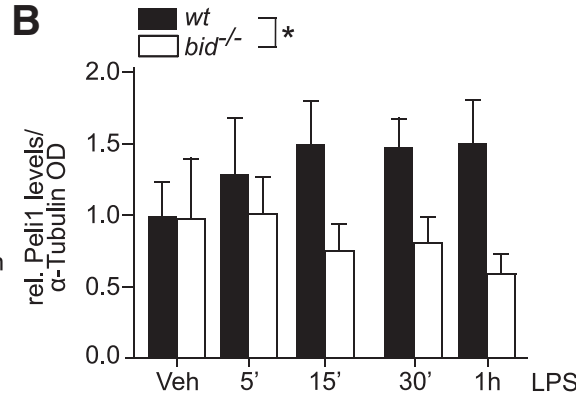

Figure 4. Peli1 levels are reduced in bid $^{-1-}$ microglia upon LPS stimulation. $\boldsymbol{A}, \boldsymbol{B}$, Peli1 levels were analyzed by Western blot analysis in wild-type and bid $^{-1-}$ microglia upon acute LPS stimulation $(\boldsymbol{B} ; n=3$ cultures from 3 separate platings; three-way ANOVA, Tukey's multiple-comparison post hoc test). Cells were stimulated with LPS (100 ng/ml) in serum-free media for the relevant treatment time points, lysed in RIPA buffer and prepared for Western blot analysis.

\section{Bid promotes TRAF6-mediated polyubiquitination} Previous studies have identified Bid and IKK $\gamma /$ NEMO association in response to inflammatory stimuli in intestinal epithelia (Yeretssian et al., 2011), as well as astrocytes. Here we identified an interaction with an upstream mediator of NEMO activation, TRAF6 (Goh et al., 2012). TRAF6, a member of the TRAF family of intracellular signaling adaptor proteins, is critical for K63-linked ubiquitination of both Peli1 and the IRAK complex (Conze et al., 2008; Goh et al., 2012; Moynagh, 2014). We found that Bid and TRAF6 coimmunoprecipitated in BV-2 cells and WT glia (Fig. 5A-C). This interaction between TRAF6 and Bid was additionally investigated in astrocytes by coimmunoprecipitation. Here we observed that TRAF6 immunoprecipitated with Bid in wild-type astrocytes upon LPS stimulation for $1 \mathrm{~h}$, an interaction that was not seen in bid-deficient astrocytes (Fig. 5D). Additionally, we used proximity-ligation assays to explore the association of Bid with TRAF6 proteins within microglia in situ. Here, a significant increase in Bid and TRAF6 close-proximities was detected upon LPS stimulation in BV-2 cells (Fig. 5E,F; 1.9 -fold increase \pm 1.24 ).

Ubiquitination is a post-translational modification that involves the formation of ubiquitin linkage chains and leads to a variety of biological processes depending on which of the seven lysine residues of ubiquitin (K6, K11, $\mathrm{K} 27, \mathrm{~K} 29, \mathrm{~K} 33, \mathrm{~K} 48, \mathrm{~K} 63$ ) are covalently conjugated to form a polyubiquitin chain (Ikeda and Dikic, 2008). In addition, recent studies have identified a hybrid K63/linear (K63/M1)-linked ubiquitin chain formation in IKK complex signaling and subsequent NF- $\kappa \mathrm{B}$ activation (Emmerich et al., 2013). As the polyubiquitination of TRAF6 is essential for the positive regulation of downstream proteins of the TLR-NF- $\kappa$ B pathway, such as NEMO, TAK1, and Peli1 we next assessed the levels of TRAF6 polyubiquitination in wild-type glial cells overexpressing Bid (Fig. 6A). Higher levels of TRAF6 polyubiquitination were present in wildtype glia compared with bid-deficient cells (Fig. 6A,B; 0.75 -fold \pm 0.41 decrease). Overexpression of Bid promoted TRAF6 polyubiquitination in glial cells, however, basal levels of Bid also showed increased TRAF6 polyubiquitination compared with bid-deficient glia (Fig. 6B,D). In addition, the impact of the absence of Bid on TRAF6 K63-linked autoubiquitination was investigated. Wild-type and $\mathrm{bid}^{-1-}$ glial cells overexpressing Bid and/or Ubiquitin-HA were stimulated with LPS for $1 \mathrm{~h}$ and TRAF6 was immunoprecipitated from these samples. Subsequent Western blot analysis of immunoprecipitated samples revealed an increased K63-linked polyubiquitination of TRAF6 in LPS stimulated wild-type microglia overexpressing ubiquitin-HA compared with $\mathrm{bid}^{-1-}$ glia overexpressing ubiquitin-HA (Fig. $6 C, D ; 0.67$-fold \pm 0.3 decrease). Next, the levels of total K63-linked ubiquitin chains were assessed in wild-type and bid-deficient microglia upon acute stimulations with LPS for $30 \mathrm{~min}$ and $1 \mathrm{~h}$ (Fig. 6E,F; 2.1-fold \pm 0.42 increase vs 1.5 -fold \pm 0.36 increase $1 \mathrm{~h}$ post-LPS stimulation). The microglia were lysed and analyzed by Western blot, using an anti-K63-linked ubiquitin chain specific antibody. Lower levels of total K63-linked ubiquitin chains were observed when Bid was absent in microglia.

\section{Discussion}

In this study, we demonstrate that Bid positively mediates microglial TLR4-NF- $\kappa$ B signaling, highlighting a nonapoptotic role of Bid in regulating immune responses in the CNS. Bid promotes the K63-linked polyubiquitination of TRAF6 upstream of IKK and absence of Bid attenuates the TLR4-induced NF- $\kappa \mathrm{B}$ proinflammatory microglial response.

There is an emerging emphasis on the role of the innate immunity in driving neurodegenerative disease progression (Nguyen et al., 2002; Zhao et al., 2010), with mounting evidence implicating a central role of microglia in ALS pathogenesis (Beers et al., 2006; Di Giorgio et al., 2007; Glass et al., 2010). TLR2 and TLR4 mediate ALS-linked mutant SOD1 toxicity, as extracellular mutant SOD1 1933 activates microglia in a CD14-dependent manner (Zhao et al., 2010; Lee et al., 2015). Here we show increased TLR2 and TLR4 levels following overexpression of SOD $1^{\mathrm{G} 93 \mathrm{~A}}$ in BV-2 cells. Moreover, the data presented demonstrates increased COX-II levels in response to SOD1 ${ }^{\text {G93A }}$, elicited through both autocrine and paracrine stimulation, further consolidating the previous findings presenting TLR2, TLR4, and NF- $\kappa$ B activation in mutant SOD1 treated microglia (Frakes et al., 2014; Lee et al., 2015). A lack of induction of Bid in microglia upon mutant SOD1 or LPS stimulation was observed (data not shown), indicating that the constitutively high levels of microglial 

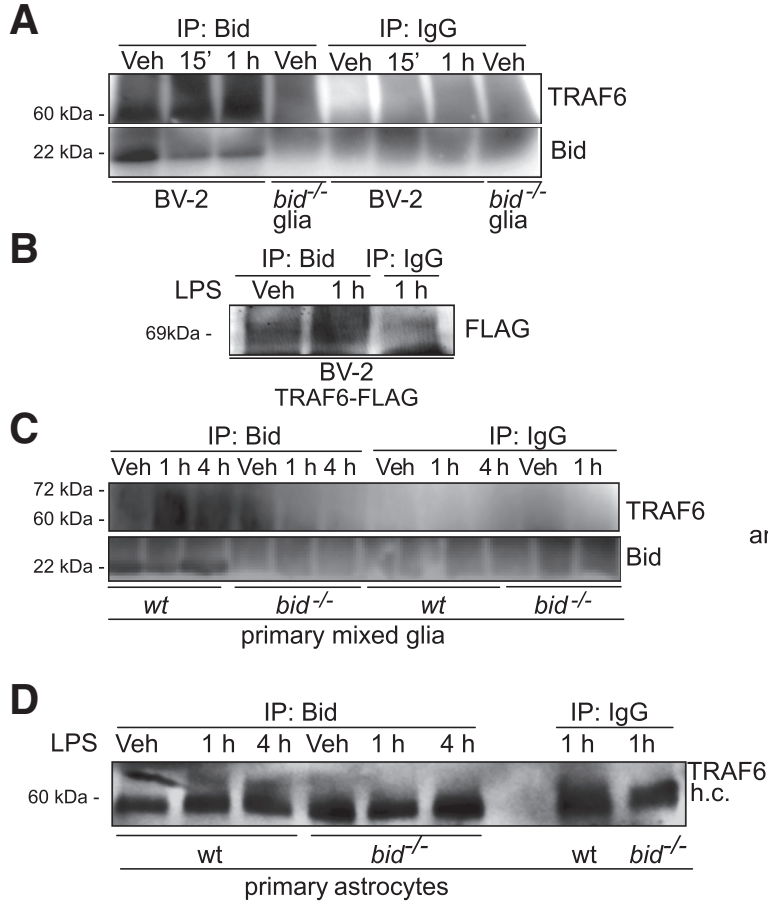

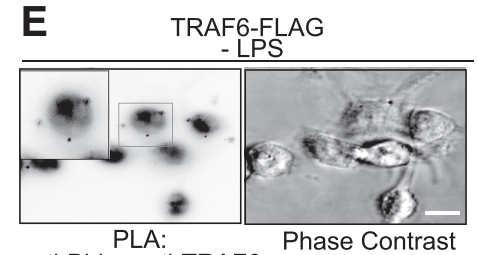

anti-Bid + anti-TRAF6

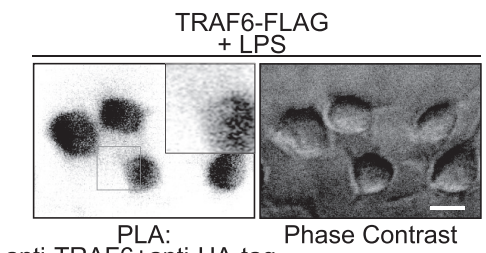

anti-TRAF6+anti-HA-tag

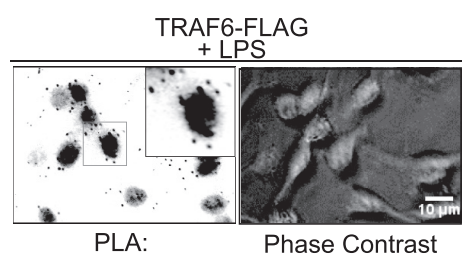

anti-Bid + anti-TRAF6

TRAF6-FLAG

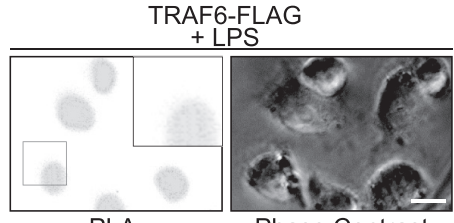

anti-Bid+anti-IRF2

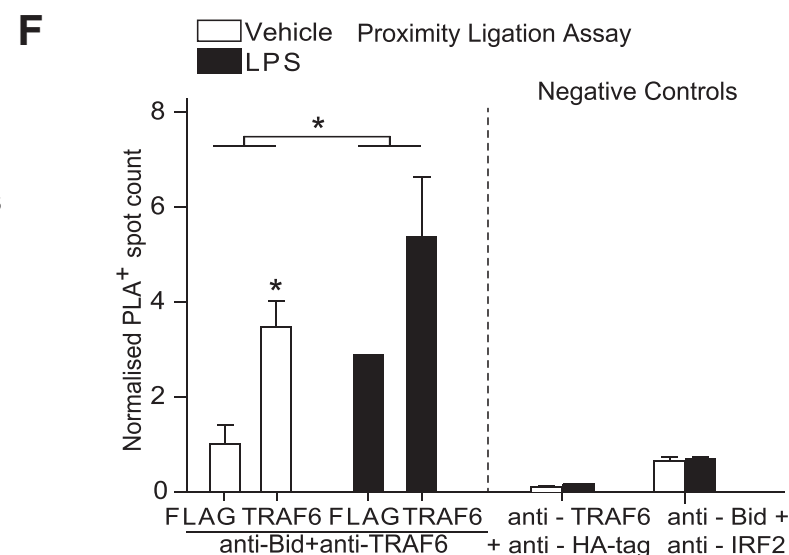

Figure 5. Bid associates with TRAF6 in microglia and astrocytes, as shown by coimmunoprecipitation and PLA. $\boldsymbol{A}$, Coimmunoprecipitation of Bid and TRAF6 in BV-2 cells. BV-2 cells were stimulated with LPS (1 $\mu \mathrm{g} / \mathrm{ml})$ for 15 min or $1 \mathrm{~h}$ and Bid was immunoprecipitated. Negative controls included anti-Bid immunoprecipitation from bid-deficient mixed glia lysates, and IgG immunoprecipitation from all samples. Cells were lysed in RIPA buffer and analyzed for TRAF6 content after immunoprecipitation of Bid. $\boldsymbol{B}$, Coimmunoprecipitation of Bid and TRAF6 in BV-2 cells overexpressing TRAF6-FLAG. BV-2 cells were stimulated with LPS (1 $\mu \mathrm{g} / \mathrm{ml}$ ) and lysed in RIPA buffer. FLAG was detected by Western blotting and represents TRAF6FLAG immunoprecipitated with Bid in BV-2 cells. An IgG immunoprecipitation was included as a negative control. $\boldsymbol{C}$, Coimmunoprecipitation of Bid and TRAF6 in WT and bid-deficient primary mixed glia stimulated with LPS for 1 and $4 \mathrm{~h}(100 \mathrm{ng} / \mathrm{ml})$. Samples were lysed post-LPS stimulation and Bid was immunoprecipitated from the lysates. The samples were analyzed for TRAF6 content by Western blotting. IgG immunoprecipitation was carried out as an additional negative control. $\boldsymbol{D}$, Coimmunoprecipitation of Bid and TRAF6 in wild-type and bid ${ }^{-1-}$ astrocytes. Purified astrocytes were stimulated with LPS $(100 \mathrm{ng} / \mathrm{ml})$ for 1 and $4 \mathrm{~h}$, and lysed in RIPA buffer for Bid immunoprecipitation. The samples were analyzed for TRAF6 by Western blotting. $\boldsymbol{E}$, Representative images of PLA and phase contrast in TRAF6-FLAG overexpressing BV-2 cells immunostained with anti-Bid and anti-TRAF6 ( $n=2$ wells/condition, 4 fields of view per well). Negative control representative images of PLA in TRAF6-FLAG overexpressing BV-2 cells immunostained with anti-TRAF6 and anti-HA-tag ( $n$ $=1$ well/condition, 6 fields of view-LPS, 1 field of view + LPS), or immunostained with anti-Bid and anti-IRF2 ( $n=1$ well/condition, 7 fields of view). Scale bar, $10 \mu \mathrm{m}$. $\boldsymbol{F}$, Quantification of PLA interactions in BV-2 cells. BV-2 cells were transfected with TRAF6-FLAG or empty FLAG vector and stimulated with LPS for $1 \mathrm{~h}$. The cells were fixed with $3 \%$ paraformaldehyde, incubated with anti-Bid and anti-TRAF6 and PLA was quantified (significant increase of PLA dots in TRAF6 transfected versus control transfected cells and vehicle vs LPS treated cells, two-way ANOVA). Negative controls included immunostaining with anti-Bid plus anti-IRF2, and anti-TRAF6 plus anti-HA-tag.

Bid are sufficient for the signaling cascade to respond to TLR4-induced stimulation.

Recent studies proposed that Bid positively regulates the immunological profile of macrophages and epithelial cells, and Bid-deficiency resulted in decreased proinflammatory cytokine mRNA levels in response to LPS in microglia (Mayo et al., 2011), and attenuated NF- $\kappa$ B activation in astrocytes (König et al., 2014). These findings are of critical importance as elevated levels of Bid are seen both in the spinal cord and activated astrocytes in the
SOD1 ${ }^{\text {G93A }}$ transgenic mouse model (Guégan et al., 2002; König et al., 2014), suggesting increased Bid levels may contribute to the chronic inflammation evident in ALS disease progression. Interestingly, TNF $\alpha$ levels increase concurrent with disease progression in mutant SOD1linked ALS pathogenesis (Hensley et al., 2003), and here we found reduced levels of TNF $\alpha$ in LPS-induced biddeficient microglia. We have demonstrated that Bid is highly expressed in unstimulated microglia, and that mi-

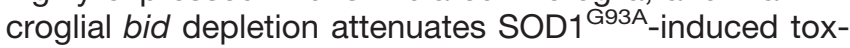


A

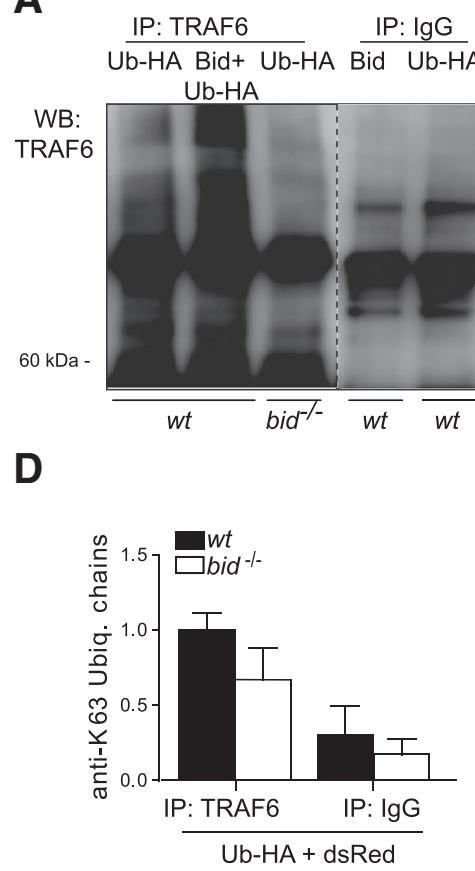

B

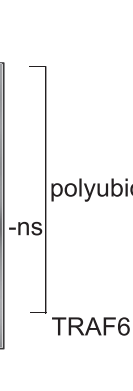

E

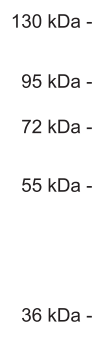

Veh

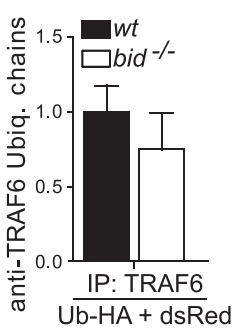

C

\begin{tabular}{|c|c|c|c|c|c|c|c|}
\hline \multirow{3}{*}{$\begin{array}{r}\text { Bid-dsRed } \\
\text { dsRed }\end{array}$} & \multicolumn{5}{|c|}{ IP: TRAF6 } & \multicolumn{2}{|c|}{$\underline{I P:} \lg G$} \\
\hline & + & + & + & - & - & + & - \\
\hline & + & - & - & + & + & - & + \\
\hline Ubiq.-HA & - & + & + & + & + & + & + \\
\hline LPS & - & - & + & - & + & + & + \\
\hline
\end{tabular}

$250 \mathrm{kDa}-$
$130 \mathrm{kDa}-$
$95 \mathrm{kDa}-$
$72 \mathrm{kDa}-$

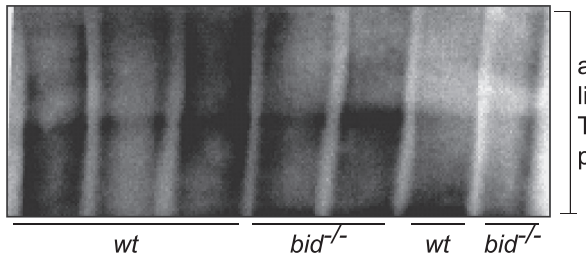

anti - K63 linked TRAF6 polyubiq.

Figure 6. Bid promotes K63-linked polyubiquitination of TRAF6. A, TRAF6 polyubiquitination levels in wild-type and bid ${ }^{-1-}$ glia. $^{-}$ TRAF6 was immunoprecipitated and TRAF6 polyubiquitination was assessed in WT mixed glia overexpressing Bid-dsRed plus Ubiquitin-HA (HA-Ub), and wild-type glia overexpressing ubiquitin-HA plus dsRed. bid $^{-1-}$ glia were transfected with ubiquitin-HA plus dsRed. Immunoprecipitation of IgG was used as an immunoprecipitation control. Single membrane cut as represented by dashed line. $\boldsymbol{B}$, Quantification of TRAF6-linked ubiquitin chains, as measured by OD in wild-type and bid $^{-/-}$glia transfected with ubiquitin-HA plus dsRed ( $n=2$ pooled from 2 separate experiments). $\boldsymbol{C}$, Wild-type and bid $^{-1-}$ glia were transfected with the following plasmids, Bid plus dsRed, ubiquitin-HA plus dsRed or Bid plus ubiquitin-HA plasmids for $24 \mathrm{~h}$ and subsequently stimulated with LPS for $1 \mathrm{~h}$. The cells were lysed in RIPA buffer. TRAF6 was immunoprecipitated from the transfected cell lysates and the samples were analyzed by Western blot. The membrane was exposed to an anti-K63-linked ubiquitin-specific antibody, which identified the K63-linked ubiquitination of TRAF6. D, Quantification of TRAF6 K63-linked ubiquitin chains, as measured by optical density in wild-type and $\mathrm{bid}^{-\prime-}$ glia transfected with ubiquitin-HA plus dsRed ( $n=2-3$ from 2-3 separate experiments). $\boldsymbol{E}$, Representative Western blot of total K63-linked ubiquitination levels in WT and bid-deficient microglia upon LPS stimulation. $\boldsymbol{F}$, Quantification of OD analyses of total K63-linked polyubiquitination in wild-type and $\mathrm{bid}^{-1-}$ microglia following LPS stimulation ( $n=3$ cultures from 3 separate experiments; $p=0.050$, one-way ANOVA, Dunn's multiple-comparison post hoc test). Wild-type and bid $^{-1-}$ microglia were treated with LPS (100 $\mathrm{ng} / \mathrm{ml}$ ) for $30 \mathrm{~min}$ or $1 \mathrm{~h}$ before lysis in RIPA buffer and K63-linked ubiquitination levels were analyzed probing with anti-K63-linked ubiquitin-specific antibodies in Western blotting experiments.

icity. The role of microglia in SOD1-mediated toxicity has been supported by studies which demonstrate that accumulation of mutant SOD1 in either motoneurons alone (Pramatarova et al., 2001) or astrocytes (Gong et al., 2000) may not be sufficient to efficiently cause motoneuron degeneration, with the addition of SOD1 ${ }^{\mathrm{G} 93 \mathrm{~A}}$ microglia to co-cultures shown to induce motoneuron death (Zhao et al., 2010). Additionally, a recent study shows that $\mathrm{NF}-\kappa \mathrm{B}$ is activated concurrently with disease progression in SOD1 ${ }^{\mathrm{G} 93 \mathrm{~A}}$ mice, and that inhibition of $\mathrm{NF}-\kappa \mathrm{B}$ in microglia rescued motoneurons from cell death in SOD1 ${ }^{\text {G93A }}$ murine cells in culture, and delayed motor function deficits in SOD1 ${ }^{\text {G93A }}$ mice (Frakes et al., 2014).

The therapeutic potential of attenuated TLR4 signalling in ALS is highlighted in studies demonstrating reduced motoneuron degeneration in SOD1 ${ }^{\mathrm{G} 93 \mathrm{~A}}$ mice lacking t/r4 (Lee et al., 2015), and in rescued SOD1 ${ }^{\mathrm{G} 93 \mathrm{~A}}$ stimulated motoneuron death in vitro using TLR4 inhibitors (De Paola et al., 2016). We demonstrate that Bid has a specific role in TLR4 signaling, as LPS primarily elicits its response via TLR4 and is a potent agonist of TLR4-mediated NF- $\kappa \mathrm{B}$ activation (Hoshino et al., 1999; Bottcher et al., 2003), inducing the pro-inflammatory M1 activated microglial phenotype (Chhor et al., 2013). Acute LPS stimulations reveal decreased phosphorylation of IKK $\alpha$ and $\operatorname{IKK} \beta$, required for activation of the IKK complex and further signaling to $\left.\right|_{\kappa} \mathrm{B} \alpha$ (Wang et al., 2001). I $\mathrm{B}^{\mathrm{B}} \alpha$ sequesters NF- $\kappa \mathrm{B}$ subunits in the cytosol inhibiting their nuclear translocation, and bid-deficient microglia showed protracted $I_{\kappa} \mathrm{B} \alpha$ degradation kinetics, indicating delayed TLR4 signaling (Mayo et al., 2011). Our data demonstrates decreased NF- $\kappa$ B activation levels in Bid-inhibited LPS-stimulated BV-2 cells. Constitutive activation of NF- $\kappa$ B in WT microglia induces both gliosis and motoneuron cell death (Frakes et al., 2014), and therefore ablating this activation may ameliorate both of these hallmarks of ALS aetiology, further highlighting a potential neuroprotective role for bid depletion in microglia. 
TLR-NF- $\kappa$ B signaling is tightly regulated by a number of E3 ubiquitin ligase proteins. It has previously been reported that the E3 ubiquitin ligase Peli1 regulates the $\mathrm{NF}-\kappa \mathrm{B}$ pathway and reduced Peli1 levels are shown to impair TLR signaling (Jiang et al., 2003). Here we identified decreased levels of Peli1 upon acute LPS stimulation in $\mathrm{bid}^{-1-}$ microglia compared with wild-type. As Peli1 facilitates the K63-linked ubiquitination of the IRAK complex (Butler et al., 2007; Ordureau et al., 2008), and subsequent downstream signaling to NF- $\kappa \mathrm{B}$, reduced Peli1 levels in bid-deficient microglia may suggest accelerated Peli1 degradation. We propose this to be a process by which Bid regulates TLR-induced NF- $\kappa \mathrm{B}$ activation.

Many studies to date have shown that the TRAF6 RING domain is essential for the activation of IKK in TLR signaling by either activation of TAK1 (Lamothe et al., 2007; Walsh et al., 2008) or the Peli1-IRAK complex (Conze et al., 2008). Additionally, inhibiting the formation of Peli1IRAK-TRAF6 interactions was identified to prevent the degradation of the NF- $\kappa \mathrm{B}$ inhibitor $\mathrm{I}_{\kappa} \mathrm{B} \alpha$ (Choi et al., 2006). We propose that an interaction between Bid and the E3 ubiquitin ligase protein TRAF6 modulates the NF- $\kappa$ B signaling pathway in microglia. Together with previous studies, our data implies a potential cell-type-specific interaction between Bid and different signaling proteins essential for NF- $\kappa \mathrm{B}$ activation. Interestingly the BidTRAF6 interaction we observe in microglia suggests that Bid may interact specifically with E3 ubiquitin ligase proteins, which regulate NF- $\kappa \mathrm{B}$ activation. Ubiquitination of multiple proteins, forming mainly K63 and M1 chains (for review, see Iwai et al., 2014), is required for NF- $\kappa$ B activation, in order for the IKK complex to become phosphorylated with subsequent K48-linked proteasomal degradation of $I_{\kappa} \mathrm{B} \alpha$, resulting in the release $\mathrm{NF}-\kappa \mathrm{B}$ into the cytosol. TRAF6 activates NF- $\kappa \mathrm{B}$ via facilitating the recruitment of the TAK1/TAB1/TAB2 complex (Lamothe et al., 2007 ) and by directly forming ubiquitin chains with NEMO (Gautheron et al., 2010) and IRAK-1 (Qian et al., 2001). We have demonstrated that Bid promotes the autoubiquitination of TRAF6, specifically K63-linked ubiquitination upon LPS stimulation. TRAF6 is autoubiquitinated by K63linked chains, preventing the K48-linked degradation of TRAF6, and providing docking sites for an array of proteins that mediate NF- $\kappa$ B activation (Chen, 2005). The requirement of TRAF6 autoubiquitination for TRAF6mediated ubiquitination of target proteins is debatable, with some studies arguing TRAF6 autoubiquitination to be unnecessary (Walsh et al., 2008; Wang et al., 2010) and other studies demonstrating that TRAF6 autoubiquitination is essential for TRAF6-mediated NEMO K63-ubiquitination and downstream NF- $\kappa \mathrm{B}$ activation (Lamothe et al., 2007). Interestingly, it has been reported that unanchored polyubiquitin chains generated by TRAF6 can activate both TAK1 and IKK complexes (Xia et al., 2009).

Additionally, TLR4 is of increasing interest in ALS therapeutics, with another agonist of TLR4, high-mobility group box 1 (HMGB1), shown to be secreted from motoneurons and to have increased reactivity in astrocytes and microglia concurrent with ALS disease progression (Lo Coco et al., 2007; Lee et al., 2015). Of note, TNF $\alpha$ secretion from NF- $\kappa \mathrm{B}$-activated glial cells provides a death receptor agonist which may contribute to the rate of motoneuron death (Aebischer et al., 2013). We propose that the Bid-potentiated polyubiquitination of TRAF6 positively regulates TLR4-induced NF- $\kappa \mathrm{B}$ signaling by promoting Peli1-IRAK-TRAF6 interactions and supporting proinflammatory signal propagation to $I_{\kappa} \mathrm{B} \alpha$ and NF- $\kappa \mathrm{B}$. Furthermore, as NF- $\kappa \mathrm{B}$ is a complex therapeutic target, a cell-specific approach may prove more effective. Depletion of microglial Bid offers a potential avenue for the regulation and attenuation of the TLR4- and TRAF6mediated inflammatory response in ALS pathogenesis.

\section{References}

Aebischer J, Bernard-Marissal N, Pettmann B, Raoul, C (2013) Death receptors in the selective degeneration of motoneurons in amyotrophic lateral sclerosis. J Neurodegener Dis 2013:746845. CrossRef Medline

Akira S, Hoshino K (2003) Myeloid differentiation factor 88dependent and -independent pathways in toll-like receptor signaling. J Infect Dis 187:S356-S363. CrossRef Medline

Alkalay I, Yaron A, Hatzubai A, Jung S, Avraham A, Gerlitz O, Pashut-Lavon I, Ben-Neriah Y (1995) In vivo stimulation of I kappa $\mathrm{B}$ phosphorylation is not sufficient to activate NF-kappa B. Mol Cell Biol 15:1294-1301. Medline

Beers DR, Henkel JS, Xiao Q, Zhao W, Wang J, Yen AA, Siklos L, McKercher SR, Appel SH (2006) Wild-type microglia extend survival in PU.1 knockout mice with familial amyotrophic lateral sclerosis. Proc Natl Acad Sci U S A 103:16021-16026. CrossRef Medline

Bottcher T, Von Mering M, Ebert S, Meyding-Lamade U, Kuhnt U, Gerber J, Nau R (2003) Differential regulation of Toll-like receptor mRNAs in experimental murine central nervous system infections. Neurosci Lett 344:17-20.

Brites D, Vaz AR (2014) Microglia centered pathogenesis in ALS: insights in cell interconnectivity. Front Cell Neurosci 8:117. CrossRef Medline

Brown K, Gerstberger S, Carlson L, Franzoso G, Siebenlist U (1995) Control of I kappa B-alpha proteolysis by site-specific, signalinduced phosphorylation. Science 267:1485-1488. Medline

Butler MP, Hanly JA, Moynagh PN (2007) Kinase-active interleukin-1 receptor-associated kinases promote polyubiquitination and degradation of the Pellino family: direct evidence for PELLINO proteins being ubiquitin-protein isopeptide ligases. J Biol Chem 282: 29729-29737. CrossRef

Cashman NR, Durham HD, Blusztajn JK, Oda K, Tabira T, Shaw IT, Dahrouge S, Antel JP (1992) Neuroblastoma x spinal cord (NSC) hybrid cell lines resemble developing motor neurons. Dev Dyn 194:209-221. CrossRef Medline

Casula M, Iyer AM, Spliet WG, Anink JJ, Steentjes K, Sta M, Troost D, Aronica E (2011) Toll-like receptor signaling in amyotrophic lateral sclerosis spinal cord tissue. Neuroscience 179:233-243. CrossRef Medline

Chen ZJ (2005) Ubiquitin signalling in the NF-kappaB pathway. Nat Cell Biol 7:758-65. CrossRef Medline

Chhor V, Le Charpentier T, Lebon S, Oré MV, Celador IL, Josserand J, Degos V, Jacotot E, Hagberg H, Sävman K, Mallard C, Gressens P, Fleiss B (2013) Characterization of phenotype markers and neuronotoxic potential of polarised primary microglia in vitro. Brain Behav Immun 32:70-85. CrossRef

Choi KC, Lee YS, Lim S, Choi HK, Lee CH, Lee EK, Hong S, Kim IH, Kim SJ, Park SH (2006) Smad6 negatively regulates interleukin 1-receptor-Toll-like receptor signaling through direct interaction with the adaptor Pellino-1. Nat Immunol 7:1057-1065. CrossRef Medline

Conze DB, Wu CJ, Thomas JA, Landstrom A, Ashwell JD (2008) Lys63-linked polyubiquitination of IRAK-1 is required for 
interleukin-1 receptor- and toll-like receptor-mediated NF-kappaB activation. Mol Cell Biol 28:3538-3547. CrossRef Medline

De Paola M, Sestito SE, Mariani A, Memo C, Fanelli R, Freschi M, Bendotti C, Calabrese V, Peri F (2016) Synthetic and natural small molecule TLR4 antagonists inhibit motoneuron death in cultures from ALS mouse model. Pharmacol Res 103:180-187.

Di Giorgio FP, Carrasco MA, Siao MC, Maniatis T, Eggan K (2007) Non-cell autonomous effect of glia on motor neurons in an embryonic stem cell-based ALS model. Nat Neurosci 10:608-14. CrossRef Medline

Dinarello CA (1997) Proinflammatory and anti-inflammatory cytokines as mediators in the pathogenesis of septic shock. Chest 112:321S-329S. Medline

Emmerich $\mathrm{CH}$, Ordureau A, Strickson S, Arthur JS, Pedrioli PG, Komander D, Cohen P (2013) Activation of the canonical IKK complex by K63/M1-linked hybrid ubiquitin chains. Proc Natl Acad Sci U S A 110:15247-15252. CrossRef Medline

Erridge C, Kennedy S, Spickett CM, Webb DJ (2008) Oxidized phospholipid inhibition of toll-like receptor (TLR) signaling is restricted to TLR2 and TLR4: roles for CD14, LPS-binding protein, and MD2 as targets for specificity of inhibition. J Biol Chem 283:24748-24759. CrossRef

Evans MC, Couch Y, Sibon N, Turner MR (2013) Inflammation and neurovascular changes in amyotrophic lateral sclerosis Mol Cell Neurosci 53:34-41.

Ferraiuolo L, Kirby J, Grierson AJ, Sendtner M, Shaw PJ (2011) Molecular pathways of motor neuron injury in amyotrophic lateral sclerosis. Nat Rev Neurol 7:616-630. CrossRef Medline

Fitzgerald KA, Rowe DC, Golenbock DT (2004) Endotoxin recognition and signal transduction by the TLR4/MD2-complex. Microbes Infect 6:1361-1367. CrossRef Medline

Frakes AE, Ferraiuolo L, Haidet-Phillips AM, Schmelzer L, Braun L, Miranda CJ, Ladner KJ, Bevan AK, Foust KD, Godbout JP, Popovich PG, Guttridge DC, Kaspar BK (2014) Microglia induce motor neuron death via the classical NF- $\kappa$ B pathway in amyotrophic lateral sclerosis. Neuron 81:1009-1023. CrossRef

Gautheron J, Pescatore A, Fusco F, Esposito E, Yamaoka S, Agou F, Ursini MV, Courtois G (2010) Identification of a new NEMO/TRAF6 interface affected in incontinentia pigmenti pathology. Hum Mol Genet 19:3138-3149. CrossRef Medline

Glass CK, Saijo K, Winner B, Marchetto MC, Gage FH (2010) Mechanisms underlying inflammation in neurodegeneration. Cell 140: 918-934. CrossRef Medline

Goh ET, Arthur JS, Cheung PC, Akira S, Toth R, Cohen P (2012) Identification of the protein kinases that activate the E3 ubiquitin ligase Pellino 1 in the innate immune system. Biochem J 441:339346. CrossRef Medline

Gong YH, Parsadanian AS, Andreeva A, Snider WD, Elliott JL (2000) Restricted expression of G86R Cu/Zn superoxide dismutase in astrocytes results in astrocytosis but does not cause motoneuron degeneration. J Neurosci 20:660-665.

Grad LI, Guest WC, Yanai A, Pokrishevsky E, O'Neill MA, Gibbs E, Semenchenko V, Yousefi M, Wishart DS, Plotkin SS, Cashman NR (2011) Intermolecular transmission of superoxide dismutase 1 misfolding in living cells. Proc Natl Acad Sci U S A 108:16398-16403. CrossRef Medline

Guégan C, Vila M, Teismann P, Chen C, Onténiente B, Li M, Friedlander RM, Przedborski S (2002) Instrumental activation of bid by caspase- 1 in a transgenic mouse model of ALS. Mol Cell Neurosci 20:553-562. Medline

He BP, Wen W, Strong MJ (2002) Activated microglia (BV-2) facilitation of TNF-alpha-mediated motor neuron death in vitro. J Neuroimmunol 128:31-38. Medline

Henn A, Lund S, Hedtjärn M, Schrattenholz A, Pörzgen P, Leist M (2009) The suitability of BV2 cells as alternative model system for primary microglia cultures or for animal experiments examining brain inflammation. ALTEX 26:83-94. Medline

Hensley K, Abdel-Moaty H, Hunter J, Mhatre M, Mou S, Nguyen K, Potapova T, Pye QN, Qi M, Rice H, Stewart C, Stroukoff K, West M (2006) Primary glia expressing the G93A-SOD1 mutation pres- ent a neuroinflammatory phenotype and provide a cellular system for studies of glial inflammation. J Neuroinflammation 3:2. CrossRef

Hensley K, Fedynyshyn J, Ferrell S, Floyd RA, Gordon B, Grammas P, Hamdheydari L, Mhatre M, Mou S, Pye QN, Stewart C, West M, West S, Williamson KS (2003) Message and protein-level elevation of tumor necrosis factor alpha (TNF $\alpha$ ) and $\mathrm{TNF} \alpha$-modulating cytokines in spinal cords of the G93A-SOD1 mouse model for amyotrophic lateral sclerosis. Neurobiol Dis 14:74-80. CrossRef

Hoshino K, Takeuchi O, Kawai T, Sanjo H, Ogawa T, Takeda Y, Takeda K, Akira S (1999) Cutting edge: Toll-like receptor 4 (TLR4)deficient mice are hyporesponsive to lipopolysaccharide: evidence for TLR4 as the Lps gene product. J Immunol 162:3749-3752. Medline

Ikeda F, Dikic I (2008) Atypical ubiquitin chains: new molecular signals. "Protein modifications: beyond the usual suspects" review series. EMBO Rep 9:536-542. CrossRef Medline

Iwai K, Fujita H, Sasaki Y (2014) Linear ubiquitin chains: NF- $\kappa B$ signalling, cell death and beyond. Nat Rev Mol Cell Biol 15:503508. CrossRef Medline

Jiang Z, Johnson HJ, Nie H, Qin J, Bird TA, Li X (2003) Pellino 1 is required for interleukin-1 (IL-1)-mediated signaling through its interaction with the IL-1 receptor-associated kinase 4 (IRAK4)-IRAKtumor necrosis factor receptor-associated factor 6 (TRAF6) complex. J Biol Chem 278:10952-10956. CrossRef

Kaufmann T, Tai L, Ekert PG, Huang DC, Norris F, Lindemann RK, Johnstone RW, Dixit VM, Strasser A (2007) The BH3-only protein bid is dispensable for DNA damage- and replicative stressinduced apoptosis or cell-cycle arrest. Cell 129:423-433. CrossRef Medline

Kielian T (2006) Toll-like receptors in central nervous system glial inflammation and homeostasis. J Neurosci Res 83:711-730. CrossRef Medline

Kieran D, Woods I, Villunger A, Strasser A, Prehn JH (2007) Deletion of the BH3-only protein puma protects motoneurons from ER stress-induced apoptosis and delays motoneuron loss in ALS mice. Proc Natl Acad Sci U S A 104:20606-20611. CrossRef Medline

Kikuchi H, Almer G, Yamashita S, Guégan C, Nagai M, Xu Z, Sosunov AA, McKhann GM 2nd, Przedborski S (2006) Spinal cord endoplasmic reticulum stress associated with a microsomal accumulation of mutant superoxide dismutase- 1 in an ALS model. Proc Natl Acad Sci U S A 103:6025-6030. CrossRef

König HG, Coughlan KS, Kinsella S, Breen BA, Prehn JH (2014) The BCL-2 family protein Bid is critical for pro-inflammatory signaling in astrocytes. Neurobiol Dis 70:99-107. CrossRef Medline

Laflamme N, Lacroix S, Rivest S (1999) An essential role of interleukin-1 beta in mediating NF-kappaB activity and COX-2 transcription in cells of the blood-brain barrier in response to a systemic and localized inflammation but not during endotoxemia. $J$ Neurosci 19:10923-10930.

Lamothe B, Besse A, Campos AD, Webster WK, Wu H, Darnay BG (2007) Site-specific Lys-63-linked tumor necrosis factor receptorassociated factor 6 auto-ubiquitination is a critical determinant of I kappa B kinase activation. J Biol Chem 282:4102-4112.

Lee JY, Lee JD2, Phipps S, Noakes PG, Woodruff TM (2015) Absence of toll-like receptor 4 (TLR4) extends survival in the hSOD1(G93A) mouse model of amyotrophic lateral sclerosis. J Neuroinflammation 12:90. CrossRef Medline

Liao B, Zhao W, Beers DR, Henkel JS, Appel SH (2012) Transformation from a neuroprotective to a neurotoxic microglial phenotype in a mouse model of ALS. Exp Neurol 237:147-152. CrossRef Medline

Liu Y, Hao W, Dawson A, Liu S, Fassbender K (2009) Expression of amyotrophic lateral sclerosis-linked SOD1 mutant increases the neurotoxic potential of microglia via TLR2. J Biol Chem 284:36913699. CrossRef Medline

Lo Coco D, Veglianese P, Allievi E, Bendotti C (2007) Distribution and cellular localization of high mobility group box protein 1 (HMGB1) 
in the spinal cord of a transgenic mouse model of ALS. Neurosci Lett 412:73-77. CrossRef Medline

Mayo L, Levy A, Jacob-Hirsch J, Amariglio N, Rechavi G, Stein R (2011) Bid regulates the immunological profile of murine microglia and macrophages. Glia 59:397-412. CrossRef Medline

Moynagh PN (2009) The Pellino family: IRAK E3 ligases with emerging roles in innate immune signalling. Trends Immunol 30:33-42. CrossRef Medline

Moynagh PN (2014) The roles of Pellino E3 ubiquitin ligases in immunity. Nat Rev Immunol 14:122-131. CrossRef Medline

Nadjar A, Tridon V, May MJ, Ghosh S, Dantzer R, Amédée T, Parnet $P(2005)$ NFkappaB activates in vivo the synthesis of inducible Cox-2 in the brain. J Cereb Blood Flow Metab 25:1047-1059. CrossRef Medline

Nakao S, Ogata Y, Shimizu-Sasaki E, Yamazaki M, Furuyama S, Sugiya $\mathrm{H}$ (2000) Activation of NFkappaB is necessary for IL-1betainduced cyclooxygenase-2 (COX-2) expression in human gingival fibroblasts. Mol Cell Biochem 209:113-8. Medline

Nguyen MD, Julien JP, Rivest S (2002) Innate immunity: the missing link in neuroprotection and neurodegeneration? Nat Rev Neurosci 3:216-227. CrossRef Medline

Ordureau A, Smith H, Windheim M, Peggie M, Carrick E, Morrice N, Cohen P (2008) The IRAK-catalysed activation of the E3 ligase function of Pellino isoforms induces the Lys63-linked polyubiquitination of IRAK1. Biochem J 409:43-52. CrossRef Medline

Pramatarova A, Laganière $\mathrm{J}$, Roussel $\mathrm{J}$, Brisebois $\mathrm{K}$, Rouleau GA (2001) Neuron-specific expression of mutant superoxide dismutase 1 in transgenic mice does not lead to motor impairment. J Neurosci 21:3369-3374. Medline

Qian Y, Commane M, Ninomiya-Tsuji J, Matsumoto K, Li X (2001) IRAK-mediated translocation of TRAF6 and TAB2 in the interleukin-1-induced activation of NFkappa B. J Biol Chem 276: 41661-41667. CrossRef Medline

Renton AE, Chiò A, Traynor BJ (2014) State of play in amyotrophic lateral sclerosis genetics. Nat Neurosci 17:17-23. CrossRef Medline

Reynolds A, Leake D, Boese Q, Scaringe S, Marshall WS, Khvorova A (2004) Rational siRNA design for RNA interference. Nat Biotechnol 22:326-330. CrossRef

Rosen DR, Siddique T, Patterson D, Figlewicz DA, Sapp P, Hentati A, Donaldson D, Goto J, O'Regan JP, Deng HX, Rahmani Z, Krizus A , Mckennayasek D, Cayabyab A, Gaston Sm, Berger R, Tanzi Re, Halperin Jj, Herzfeldt B, Vandenbergh R, et al. (1993) Mutations in $\mathrm{Cu} / \mathrm{Zn}$ superoxide dismutase gene are associated with familial amyotrophic lateral sclerosis. Nature 362:59-62. CrossRef Medline

Rotunno MS, Bosco DA (2013) An emerging role for misfolded wild-type SOD1 in sporadic ALS pathogenesis. Front Cell Neurosci 7:253. CrossRef Medline

Sargsyan SA, Blackburn DJ, Barber SC, Monk PN, Shaw PJ (2009) Mutant SOD1 G93A microglia have an inflammatory phenotype and elevated production of MCP-1. Neuroreport 20:1450-1455. CrossRef Medline

Sawada M, Kondo N, Suzumura A, Marunouchi T (1989) Production of tumor necrosis factor-alpha by microglia and astrocytes in culture. Brain Res 491:394-397. Medline

Scheffel J, Regen T, Van Rossum D, Seifert S, Ribes S, Nau R, Parsa R, Harris RA, Boddeke HW, Chuang HN, Pukrop T, Wessels JT, Jürgens T, Merkler D, Brück W, Schnaars M, Simons M, Kettenmann H, Hanisch UK (2012) Toll-like receptor activation reveals developmental reorganization and unmasks responder subsets of microglia. Glia 60:1930-43. CrossRef

Sebastià J, Kieran D, Breen B, King MA, Netteland DF, Joyce D, Fitzpatrick SF, Taylor CT, Prehn JH (2009) Angiogenin protects motoneurons against hypoxic injury. Cell Death Differ 16:12381247. CrossRef Medline

Soderberg O, Gullberg M, Jarvius M, Ridderstråle K, Leuchowius KJ, Jarvius J, Wester K, Hydbring P, Bahram F, Larsson LG, Landegren $U$ (2006) Direct observation of individual endogenous protein complexes in situ by proximity ligation. Nat Methods 3:995-1000. CrossRef Medline

Song X, Qian Y (2013) Peli1 sets the CNS on fire. Nat Med 19:536538. CrossRef Medline

Stack J, Bowie AG (2012) Poxviral protein A46 antagonizes Toll-like receptor 4 signaling by targeting BB loop motifs in Toll-IL-1 receptor adaptor proteins to disrupt receptor:adaptor interactions. J Biol Chem 287:22672-22682. CrossRef Medline

Suzumura A, Sawada M, Yamamoto H, Marunouchi T (1990) Effects of colony stimulating factors on isolated microglia in vitro. J Neuroimmunol 30:111-120. Medline

Takeuchl O, Hoshino K, Kawai T, Sanjo H, Takada H, Ogawa T, Takeda K, Akira S (1999) Differential roles of TLR2 and TLR4 in recognition of gram-negative and gram-positive bacterial cell wall components. Immunity 11:443-451. Medline

Tu O, Hoshino K, Kawai T, Sanjo H, Takada H, Ogawa T, Takeda K, Akira S (1996) Transgenic mice carrying a human mutant superoxide dismutase transgene develop neuronal cytoskeletal pathology resembling human amyotrophic lateral sclerosis lesions. Proc Natl Acad Sci U S A 93:3155-3160. CrossRef

Walsh MC, Kim GK, Maurizio PL, Molnar EE, Choi Y (2008) TRAF6 autoubiquitination-independent activation of the $\mathrm{NF} \kappa \mathrm{B}$ and MAPK pathways in response to IL-1 and RANKL. PLoS One 3:e4064. CrossRef

Wang C, Deng L, Hong M, Akkaraju GR, Inoue J, Chen ZJ (2001) TAK1 is a ubiquitin-dependent kinase of MKK and IKK. Nature 412:346-351. CrossRef Medline

Wang K, Yin XM, Chao DT, Milliman CL, Korsmeyer SJ (1996) BID: a novel BH3 domain-only death agonist. Genes Dev 10:2859-69. Medline

Wang KZ, Galson DL, Auron PE (2010) TRAF6 is autoinhibited by an intramolecular interaction which is counteracted by transubiquitination. J Cell Biochem 110:763-771. CrossRef Medline

Xia ZP, Sun L, Chen X, Pineda G, Jiang X, Adhikari A, Zeng W, Chen ZJ (2009) Direct activation of protein kinases by unanchored polyubiquitin chains. Nature 461:114-119. CrossRef Medline

Xiao Q, Zhao W, Beers DR, Yen AA, Xie W, Henkel JS, Appel SH (2007) Mutant SOD1(G93A) microglia are more neurotoxic relative to wild-type microglia. J Neurochem 102:2008-2019. CrossRef Medline

Yang F, Tang E, Guan K, Wang CY (2003) IKK beta plays an essential role in the phosphorylation of RelA/p65 on serine 536 induced by lipopolysaccharide. J Immunol 170:5630-5635. Medline

Yeretssian G, Correa RG, Doiron K, Fitzgerald P, Dillon CP, Green DR, Reed JC, Saleh M (2011) Non-apoptotic role of BID in inflammation and innate immunity. Nature 474:96-99. CrossRef Medline

Zhao W, Beers DR, Henkel JS, Zhang W, Urushitani M, Julien JP, Appel SH (2010) Extracellular mutant SOD1 induces microglialmediated motoneuron injury. Glia 58:231-243. CrossRef Medline 